\title{
Cottonseed Protein, Oil, and Mineral Nutrition in Near-Isogenic Gossypium hirsutum Cotton Lines Expressing Leaf Color Phenotypes under Field Conditions
}

\author{
Nacer Bellaloui1 ${ }^{*}$, Rickie B. Turley ${ }^{1}$, Salliana R. Stetina ${ }^{1}$, William T. Molin² \\ ${ }^{1}$ USDA, Agriculture Research Service, Crop Genetics Research Unit, Stoneville, Mississippi, USA \\ ${ }^{2}$ USDA, Agriculture Research Service, Crop Production Systems Research Unit, Stoneville, Mississippi, USA \\ Email: *nacer.bellaloui@ars.usda.gov
}

How to cite this paper: Bellaloui, N., Turley, R.B., Stetina, S.R. and Molin, W.T. (2019) Cottonseed Protein, Oil, and Mineral Nutrition in Near-Isogenic Gossypium hirsutum Cotton Lines Expressing Leaf Color Phenotypes under Field Conditions. Food and Nutrition Sciences, 10, 834-859. https://doi.org/10.4236/fns.2019.107061

Received: May 18, 2019

Accepted: July 27, 2019

Published: July 30, 2019

Copyright ( 2019 by author(s) and Scientific Research Publishing Inc. This work is licensed under the Creative Commons Attribution International License (CC BY 4.0).

http://creativecommons.org/licenses/by/4.0/ (c) (i) Open Access

\begin{abstract}
Information about the effects of phenotype traits on cottonseed protein, oil, and nutrients is scarce. The objective of this research was to investigate the effects of leaf color trait on seed nutrition in near-isogenic Gossypium hirsutum cotton expressing green $(\mathrm{G})$ and yellow (Y) leaf color phenotypes. Our hypothesis was that leaf color can influence the accumulation of nutrients in seeds. Sets of isogenic lines were: DES 119 (G) and DES 119 (Y); DP 5690 (G) and DP $5690(\mathrm{Y})$; MD 51ne (G) and MD 51ne (Y); SG $747(\mathrm{G})$ and SG 747 (Y). Each NIL set is $98.44 \%$ identical. Parent line SA $30(\mathrm{P})$ was used as the control. The experiment was repeated for two years (2014 and 2015). The results showed that, in 2014, seed oil in DES 119 (G) and SG 747 (G) were significantly higher than their equivalent yellow lines. Green lines showed higher content of phosphorus compared with yellow lines. Higher levels of $\mathrm{Cu}, \mathrm{Fe}$, $\mathrm{Mn}, \mathrm{Ni}$, and $\mathrm{Zn}$ were recorded in DES 119 (G) and MD 51ne (G). In 2015, seed protein, oil, $\mathrm{C}, \mathrm{N}, \mathrm{P}, \mathrm{B}, \mathrm{Cu}$, and $\mathrm{Fe}$ were higher in green lines than in yellow lines. There was a significant correlation between protein and nutrients, and between oil and nutrients in 2015, but not in 2014 as the temperature was warmer in 2015 than in 2014. This research demonstrated that leaf color can alter seed composition and mineral nutrition under certain environmental growing conditions such as temperature.
\end{abstract}

\section{Keywords}

Isogenic Cotton, Cottonseed, Seed Protein, Seed Oil, Seed Composition 


\section{Introduction}

Cotton is a major crop in the world [1] and cottonseed is a major source of fiber, oil, proteins, and considered as a nutritious ingredient in animal feed and human food products [2] [3] [4]. In addition to its content of protein and oil [5], cottonseed contains minerals [1] [6], and is used as renewable biofuel [7]. A cotton plant produces about $1.6 \mathrm{~kg}$ of seed for every $\mathrm{kg}$ of lint, and after ginning, the seeds are either used as animal feed or processed to products, including oil, meal, hull and short linter fibers [8] [9]. Because of the high content of protein and oil in seed (about 17\% - 27\% oil and 12\% - 32\% protein) [1] [10], cotton is the fifth largest oil crop in the world and is the second largest potential source of plant protein. Due to the large demand for cottonseed fiber by the textile industry, cottonseed quality has been relatively neglected, and as a result, narrowing the genetic variation of cotton for seed quality improvement through breeding. Therefore, a deeper understanding of metabolic processes that determine the storage reserves in seeds is critical for higher seed yield and quality. The seed and its embryo are the sites of accumulation of storage reserves and secondary metabolites. Recent research revealed biochemical, cellular, and molecular mechanisms underlying biogenesis of seed storage compounds and secondary metabolites, and identified several genes involved in these processes that were essential for our understanding in improving nutritional seed qualities and enhanced functional properties of seeds [4]. However, in spite of novel approaches used by researchers, including agricultural practices and integrated management strategies [4] [6] [7]; traditional and molecular genetics [4]; quantitative trait loci mapping [1]; transformation [11]; transcriptome, molecular biology, and physiology [12]; functional genomics [13]; photosynthesis and carbon metabolism [4] [14] [15]; and gene modification and gene silencing [16] [17], achieving higher yield is still challenging, and information to select for higher cottonseed nutritional qualities is still scarce. Maintaining higher cottonseed production, fiber quality, and seed nutritional qualities is critical for textile, human nutrition, and meal industries.

The predominant cotton species grown in the USA is upland cotton, Gossypium hirsutum [18] [19] [20]. Other species, including G. barbadense, $G$. arboreum, and $G$. herbaceum are also grown and represent $5 \%$ worldwide production [13]. Breeding for cotton yield and fiber quality has been the major goal of researchers. However, it has been reported that the selection for higher yield, due to increased dry matter in the reproductive growth [14] [21], will be inefficient due to the fact that the photosynthesizing leaf area becomes the major limiting factor [14]. Therefore, it was concluded that the variation of photosynthetic components had a narrow range, making it challenging to choose for superior breeding lines [22]. Although serious attention was given to new approaches for higher yield and seed nutritional qualities, for example, cotton genome research [16] [17], cotton breeding [1], sustainable agricultural practices [23], and agronomic strategies [24] [25], achieving higher yield became chal- 
lenging due to lower use efficiency [26] [27] [28] [29] is still the main challenge worldwide [7].

Based on the above reports, new tools need to be discovered to achieve higher yield and higher seed nutritional qualities [30]. For example, previous research used cotton mutants and isogenic breeding lines to show their significant role in understanding fiber development [31] [32], yield [20], and cottonseed protein, oil, and mineral nutrition [33] [34]. Our focus in this research was to use a novel approach to understand the effects of leaf color on cottonseed composition constituents (protein and oil), N, S, and mineral nutrients using four sets of nearisogenic breeding lines, expressing leaf color phenotypes under Mississippi Delta conditions.

\section{Materials and Methods}

\subsection{Development of Near-Isogenic Lines}

The details of NILs development was reported elsewhere [35]. Briefly, the NILs were developed by the standard backcross breeding method. The NILs were developed for virescent (yellow) and wild-type (green) leaf sets from four modern upland cotton genotypes. The four modern genotypes, selected in 1995 as the wild-type parents, were cultivars DP5690 (Monsanto Company, St. Louis, MO, USA; PVPC 009100116), SG747 (Monsanto Company, St. Louis, MO, USA; PVPC 009800118), DES 119 (Mississippi Agricultural and Forestry Experiment Station, Mississippi State, MS, USA; PI 606809; PVPC 008500176) and MD51ne (USDA-ARS, Stoneville, MS, USA; PI 566941). The parent plants were selfed through 9 generations using single seed descent in insect-controlled greenhouses and using selfing bags in the field placing them over flower buds before flowering. The F1 seeds from each cross were grown and self-fertilized and the F2 seed were then planted and the segregating yellow plants were used in the backcrossing events. Then the parent lines were used to cross once and proceed to the F2 generation then begin the $\mathrm{BC} 1 \mathrm{~F} 1$ to $\mathrm{BC} 5 \mathrm{~F} 1$ with the subsequent $\mathrm{BC} 1 \mathrm{~F} 2$ to $\mathrm{BC} 5 \mathrm{~F} 2$ generations being produced in the greenhouse during fall and winter. After six years of crossing/back crossing, BC5F2, NILs expressing the two leaf colors were selected for the four upland cotton genotypes. Therefore, after the 11 years of development, we then had to increase seed for 2 years by bag-selfing using the greenhouse. Theoretically, each NIL set was $98.44 \%$ identical. Seed increases were obtained from individual plants by self-pollination in the greenhouse or in the field. Pollinating insects were prevented by the use of screens and insecticides, and cross-pollination of field grown flowers was avoided by placing $10.2 \times 15.2 \mathrm{~cm}$ organza bags (Gifts International, Ontario, CA) over the flower buds prior to opening to prevent pollinators. Validation occurred in a previous paper [35], using an obsolete verses modern cotton line study. The SA 30 line had large bolls being a derivative of Mebane type cotton. One of the observations for modern line cotton is that they have smaller bolls than the obsolete lines and in all the modern backgrounds the yellow lines produced smaller bolls with 
higher total yields. This is an indication of "changing the genotype" from the Mebane type cotton to predominantly a modern line cotton with their respective yield and fiber qualities resembling the parental modern lines. Two groups [36] [37] have mapped this gene and reported the data and what gene it is supposed to be; a single modification from arginine (Arg) to lysine (Lys) in a protein. Sequencing of NILs has taken place using the Ligon lintless lines and the gene for Ligon lintless was identified using Li1 and DP 5690 markers.

\subsection{Field Management and Growth Conditions}

A field experiment was conducted in 2014 and repeated in 2015 in Stoneville, MS. The near-isogenic lines for virescent (yellow) and wild-type (green) leaf sets were developed by a backcross breeding method using four modern upland cotton varieties (line development was detailed by others) [35]. The four modern upland cotton genotypes/cultivars were selected in 1995, and were: DP 5690 (Monsanto Company, St. Louis, MO, USA; PVPC 009100116), SG 747 (Monsanto Company, St. Louis, MO, USA; PVPC 009800118), DES 119 (Mississippi Agricultural and Forestry Experiment Station, Mississippi State, MS, USA; PI 606809; PVPC 008500176) and MD 51ne (USDA-ARS, Stoneville, MS, USA; PI 566941). These parental lines were self-pollinated to develop pure inbred lines by single seed descent selection through nine generations in greenhouse and field at the USDA-ARS in Stoneville, MS. The virescent line SA 30 (PI 528447) was used as a parent (SA 30 was obtained from the Mississippi Obsolete Variety Collection [36]. After six years of crossing, the following four sets of $\mathrm{BC}_{5} \mathrm{~F}_{2}$ NILs expressing the leaf color (green, G; yellow, Y) were developed: DES $119(\mathrm{G})$ and DES 119 (Y); DP 5690 (G) and DP $5690(\mathrm{Y})$; MD 51ne (G) and MD 51ne (Y); SG 747 (G) and SG 747 (Y). Each NIL set was theoretically 98.44\% identical. The green NILs with the parent SA 30 were planted at Stoneville, MS, the USA in 2014 and repeated in 2015 as described in detail elsewhere [35]. Briefly, plants were planted in four rows spaced of $1.02 \mathrm{~m}$ apart. Each plot was $9.14 \mathrm{~m}$ long with a $3.04 \mathrm{~m}$ alley between plots. The soil was a Bosket very fine sandy loam soil (fine-loamy, mixed, active, thermic Mollic Hapludalfs). Plots were managed in the season following recommended agronomic and pest control practices for the state of Mississippi (Mississippi State University Extension). Planting dates were May 5, 2014 and April 30, 2015, and harvesting dates were October 9, 2014 and October 8, 2015. Soil and leaf samples were taken before first square to check the nutrient levels in soil and leaves. Mature seeds were hand harvested, ginned, and delinted prior to seed composition and mineral nutrition analyses as described below.

\subsection{Soil Nutrients Analysis}

Soil analysis for nutrient levels in soil was conducted by inductively coupled plasma spectrometry (Thermo Jarrell-Ash Model 61E ICP and Thermo Jarrell-Ash Autosampler 300 (C Jarrell-Ash Corporation, Waltham, MA, USA) as 
previously detailed [38]. Briefly, the analysis was conducted on $5 \mathrm{~g}$ soil:20 $\mathrm{ml}$ Mehlich-1 solution. Analysis of N, S, and C were based on the Pregl-Dumas method [39] [40] [41] using a C/N/S elemental analyzer with thermal conductivity cells (LECOCNS-2000 elemental analyzer, LECO Corporation, St. Joseph, MI, USA). Oxygen atmosphere at $1350^{\circ} \mathrm{C}$ was used to combust soil samples and to convert elemental $\mathrm{N}, \mathrm{S}$, and $\mathrm{C}$ into $\mathrm{N}_{2}, \mathrm{SO}_{2}$, and $\mathrm{CO}_{2}$ gases. The content of $\mathrm{N}, \mathrm{S}$, and $\mathrm{C}$ in soil was analyzed by the elemental analyzer as previously detailed [38]. Soil analysis showed no soil or leaf nutrient deficiencies. The following are averages of nutrient content in soil across the field: $\mathrm{C}=0.92 \%, \mathrm{~N}=0.092 \%$; and $\left(\mathrm{g} \cdot \mathrm{kg}^{-1}\right) \mathrm{P}=0.355, \mathrm{~K}=2.27, \mathrm{~S}=0.091, \mathrm{Ca}=3.5, \mathrm{Mg}=3.0$, and $\mathrm{Fe}=18.7$; and $\left(\mathrm{mg} \cdot \mathrm{kg}^{-1}\right) \mathrm{B}=2.2, \mathrm{Cu}=13.0, \mathrm{Zn}=57.5$. Organic matter in soil was $3.3 \%$. The crop did not show any nutrient deficiency symptoms under these conditions.

\subsection{Analysis of Seed Minerals, N, S, and C}

Nutrient content in seed was determined in the ground, dried samples. Samples were ground with a Laboratory Mill 3600 (Perten, Springfield, IL, USA) and analyzed by digesting a $0.6 \mathrm{~g}$ in $\mathrm{HNO}_{3}$ in a microwave digestion system and nutrients were quantified using inductively coupled plasma spectrometry (Thermo Jarrell-Ash Model 61E ICP and Thermo Jarrell-Ash Autosampler 300) [38]. Seed $\mathrm{N}, \mathrm{C}$, and $\mathrm{S}$ were determined on $0.25 \mathrm{~g}$ samples by the $\mathrm{C} / \mathrm{N} / \mathrm{S}$ elemental analyzer as detailed previously [38] [42].

\subsection{Determination of Seed B, Fe and P}

Boron concentration in mature seeds was determined by the azomethine- $\mathrm{H}$ method [43] [44]. Briefly, seed samples were ground in a Laboratory Mill 3600 (Perten, Springfield, IL, USA) and a $1.0 \mathrm{~g}$ sample was combusted to ash at $500^{\circ} \mathrm{C}$ and extracted with $20 \mathrm{ml}$ of $2 \mathrm{M} \mathrm{HCl}$ at $90^{\circ} \mathrm{C}$ for $10 \mathrm{~min}$. The mixture was filtered and a $2 \mathrm{ml}$ sample added to $4 \mathrm{ml}$ of buffer solution containing $25 \%$ ammonium acetate, $1.5 \%$ EDTA, and $12.5 \%$ acetic acid. A freshly prepared solution (4 $\mathrm{ml}$ ) of $0.45 \%$ azomethine- $\mathrm{H}$ in $1 \%$ of ascorbic acid [45] was added, and the $\mathrm{B}$ concentration was measured at $420 \mathrm{~nm}$ using a Beckman Coulter DU 800 spectrophotometer (Beckman Coulter, Inc., Brea, CA, USA). Iron concentration in mature seeds was determined according to established methods [46] [47]. Briefly, seed samples were ground in a Laboratory Mill 3600 (Perten, Springfield, IL, USA) as described above. Then, samples were digested with hydrochloric acid (109 $\mathrm{ml}$ of $3 \% \mathrm{w} / \mathrm{w}$ ) and extracted. The concentration of $\mathrm{Fe}$ was determined based on the color complex reaction between ferrous $\mathrm{Fe}$ with 1,10-phenanthroline as described by others [38] [42]. Phenanthroline reagent solution of $0.25 \%(w / v)$ in $25 \%(\mathrm{v} / \mathrm{v})$ ethanol and quinol solution ( $1 \% \mathrm{w} / \mathrm{v})$ were prepared, and the concentrations of $\mathrm{Fe}$ ranging from 0.0 to $4 \mu \mathrm{g} \cdot \mathrm{ml}^{-1}$ of $\mathrm{Fe}$ in $0.4 \mathrm{M} \mathrm{HCl}$ were made for the standard curve. Iron concentration was measured by a Beckman Coulter DU 800 spectrophotometer at an absorbance of $510 \mathrm{~nm}$ as previously described by others [38] [42]. Phosphorus concentration in mature seeds was determined by the 
yellow phosphor-vanado-molybdate complex method [48], and as previously described [38] [42]. The $\mathrm{P}$ was extracted with $2 \mathrm{ml}$ of $36 \% \mathrm{v} / \mathrm{v} \mathrm{HCl}$. A reagent of $5 \mathrm{ml}$ of $5 \mathrm{M} \mathrm{HCl}$ and $5 \mathrm{ml}$ of ammonium molybdate-ammonium metavanadate was used. The concentration of $\mathrm{P}$ was determined by reading the absorbance at $400 \mathrm{~nm}$ using a Beckman Coulter DU 800 spectrophotometer as previously described by others [38] [42].

\subsection{Cottonseed Protein and Oil Analysis}

Mature seeds were collected from each plot and analyzed for protein and oil content. Approximately $25 \mathrm{~g}$ of seed was ground using a Laboratory Mill 3600 (Perten, Springfield, IL, USA). The content of protein and oil in cottonseed were analyzed by near infrared reflectance [33], using a diode array feed analyzer AD 7200 (Perten, Springfield, IL, USA). Calibrations were developed using Perten's Thermo Galactic Grams PLS IQ software, and the calibration equation was established according to AOAC methods [49] [50]. Protein and oil were expressed on a seed dry matter basis [33] [34].

\subsection{Experimental Design and Statistical Analyses}

The experiment was a randomized complete block design with three replications. The main plot treatment was a line (four sets of NILs and the virescent parent SA 30 were used). Statistical analyses were performed using PROC MIXED (SAS, SAS Institute, 2002-2010) [51]. Replicate (Rep) within year, and treatment by replicating within year [(Rep (Year); $\mathrm{T} \times$ Rep (Year)] were considered as random effects. Year and line were modeled as fixed effects. Residuals of the random effect factors are shown as covariance parameters in the tables. The residuals refer to Restricted Maximum Residual Likelihood (REML) values, which reflect the total variance of the random parameters in the model [34]. Means were separated using Fisher's protected least significant difference test at significant level of $5 \%$ using SAS (SAS Institute, 2002-2010) [51]. Correlations were conducted using Proc Corr in SAS. Since year by line interactions were significant for some seed composition components and mineral nutrition, results were presented separately in each year.

\section{Results}

\subsection{Analysis of Variance}

Analysis of variance showed that there was a significant effect of year for protein, but no significant differences of line or year by line interaction for protein (Table 1). There was a significant effect of year and line for oil, but no significant differences of year by line interactions for oil. Significant effects of year, line, and their interaction for C, N, P, B, Cu, Fe, and Mn content were observed. Only the line by year interaction was significant for $\mathrm{S}$. Potassium was affected only by year. Calcium was affected by year and line, but no significant effects of year by line interaction was observed. Both $\mathrm{Ni}$ and $\mathrm{Zn}$ were significantly affected by line and year by line interactions. 
Table 1. Analysis of variance of the effects of year, line, and their interactions for seed composition (\%: protein and oil; N, C, S, P, $\mathrm{K}, \mathrm{Ca}(\%) ; \mathrm{B}, \mathrm{Cu}, \mathrm{Fe}, \mathrm{Mn}, \mathrm{Ni}$, and $\mathrm{Zn}\left(\mathrm{mg}^{\mathrm{kg}} \mathrm{kg}^{-1}\right)$ in near-isogenic cotton lines expressing green or yellow leaf color and their virescent parent. The experiment was conducted in Stoneville, MS in 2014 and 2015.

\begin{tabular}{|c|c|c|c|c|c|c|c|c|c|c|c|c|c|c|c|}
\hline \multirow{2}{*}{ Effect } & \multicolumn{3}{|c|}{ Protein } & \multicolumn{2}{|l|}{ Oil } & \multicolumn{2}{|l|}{$\mathrm{C}$} & \multicolumn{2}{|l|}{$\mathrm{N}$} & \multicolumn{2}{|l|}{$S$} & \multicolumn{2}{|l|}{$\mathrm{P}$} & \multicolumn{2}{|l|}{ K } \\
\hline & DF & $\mathrm{F}$ & $\mathrm{P}$ & F & $\mathrm{P}$ & F & $\mathrm{P}$ & F & $\mathrm{P}$ & F & $\mathrm{P}$ & F & $\mathrm{P}$ & F & $\mathrm{P}$ \\
\hline Year & 1 & 10.43 & $* *$ & 6.63 & * & 45.41 & $* * *$ & 36.05 & $* * *$ & 3.39 & NS & 148.58 & $* * *$ & 4.91 & * \\
\hline Line & 8 & 1.90 & NS & 3.69 & $* *$ & 18.68 & $* * *$ & 18.54 & $* * *$ & 1.95 & NS & 24.30 & $* * *$ & 0.99 & NS \\
\hline Year ${ }^{\star}$ Line & 8 & 1.87 & NS & 1.07 & NS & 13.88 & $* * *$ & 3.81 & $* * *$ & 5.02 & $* * *$ & 2.25 & * & 1.64 & NS \\
\hline Residuals & & 5.16 & & 4.80 & & 0.67 & & 0.11 & & 0.0012 & & 0.0018 & & 0.02 & \\
\hline Effect & & $\mathrm{Ca}$ & & B & & $\mathrm{Cu}$ & & $\mathrm{Fe}$ & & $\mathrm{Mn}$ & & $\mathrm{Ni}$ & & $\mathrm{Zn}$ & \\
\hline Year & & 22.56 & $* * *$ & 73.79 & $* * *$ & 5.66 & * & 122.38 & $* * *$ & 67.39 & $* * *$ & 2.05 & NS & 4.27 & NS \\
\hline Line & & 16.66 & $* * *$ & 8.19 & $* * *$ & 12.55 & $* * *$ & 42.48 & $* * *$ & 23.64 & $* * *$ & 15.56 & $* * *$ & 51.42 & $* * *$ \\
\hline Year ${ }^{\star}$ Line & & 0.41 & NS & 2.64 & * & 5.50 & $* * *$ & 1.11 & * & 3.88 & $* * *$ & 7.59 & $* * *$ & 2.56 & * \\
\hline Residuals & & 0.0001 & & 0.47 & & 0.51 & & 8.39 & & 0.52 & & 0.17 & & 2.18 & \\
\hline
\end{tabular}

${ }^{*}$ Significant at $P \leq 0.05 ;{ }^{* *}$ significant at $P \leq 0.01 ;{ }^{* * *}$ significant at $P \leq 0.001$.

\subsection{Effects of Leaf Color on Seed Protein, Oil, C, N, S, and Minerals}

In 2014, the mean value showed that leaf color did not have a clear pattern effect on seed protein (Table 2). Seed oil in SG747 (G) was significantly higher than the SG 747 (G). The parent (P) line (SA 30) [(SA 30 (P)], control, was also competitive $(28.90 \%)$ compared with other lines. Since the oil and protein generally have an inverse correlation, protein in some lines generally showed the opposite trend. Carbon content in DES $119(\mathrm{G})$, DES 119 (Y), and DP $5690(\mathrm{G})$ was significantly higher than DP 5690 (Y), SA 30 (P), MD 5ne (G), MD 5ne (Y), SG 747 (G), and SG $747(\mathrm{Y})$; lower levels of C were recorded in SG $747(\mathrm{G})$ and SG 747 (Y). Nitrogen content in DES 119 (G), DES 119 (Y), DP 5690 (G), MD 51ne (G), SG $747(\mathrm{G})$, and SG $747(\mathrm{Y})$ was higher than DP 5690 (Y), SG 747 (G), and SG 747 (Y), but the lowest N content was recorded in DP 5690 (Y). Sulfur content in DES $119(\mathrm{G})$,

DES 119 (Y), SG 747 (G), and SG 747 (Y) were higher than DP 5690 (G), DP $5690(\mathrm{Y})$, and MD 51ne (G), and lower levels of $S$ content were recorded in these lines. Calcium was higher in all $\mathrm{G}$ lines than their equivalent $\mathrm{Y}$ lines. The parent line, SA 30 (P), also showed higher Ca content than DES 119 (Y), DP $5690(\mathrm{G})$, DP 5690 (Y), MD 51ne (Y), and SG 747 (Y). Potassium did not show variability among the lines, except for DP $5690(\mathrm{Y})$, where the lowest $\mathrm{K}$ content was observed. Potassium content in DP 5690 (G) was higher than in its equivalent line DP 5690 (G). Green lines showed higher content of P compared to yellow lines, including the SA $30(\mathrm{P})$, and high levels of $\mathrm{P}$ content were recorded in DES 119 (G) and DP 5690 (G), and low levels of P content were in SA 30 (P) and MD 51ne (Y). Boron content was the highest in DES $119(\mathrm{G})$, but the lowest in DP $5690(\mathrm{Y})$, and the rest of the lines, including SA30 (P), showed an intermediate level of B concentration. Except for MD 51ne (G), all G lines showed higher B 
Table 2. Effect of leaf color (green, G; and yellow, $\mathrm{Y}$ ) on seed composition (protein and oil expressed as \%), and nutrients ( $, \mathrm{C}, \mathrm{S}, \mathrm{K}, \mathrm{P}$, and Ca were expressed as \%; B, Cu, Fe, $\mathrm{Mn}, \mathrm{Ni}$, and $\mathrm{Zn}$ were expressed as $\mathrm{mg} \cdot \mathrm{kg}^{-1}$ ) in four sets of near-isogenic cotton lines and their virescent parent grown in Stoneville, MS in 2014.

\begin{tabular}{cccccccc}
\hline Line & Protein & Oil & $\mathrm{C}$ & $\mathrm{N}$ & $\mathrm{S}$ & $\mathrm{Ca}$ & $\mathrm{K}$ \\
\hline DES 119 (G) & 21.44 & 29.92 & 55.41 & 4.37 & 0.48 & 0.17 & 1.27 \\
DES 119 (Y) & 20.42 & 28.58 & 55.41 & 4.42 & 0.48 & 0.14 & 1.22 \\
DP 5690 (G) & 22.88 & 29.90 & 56.85 & 4.70 & 0.37 & 0.14 & 1.27 \\
DP 5690 (Y) & 21.84 & 29.06 & 54.74 & 3.20 & 0.37 & 0.11 & 0.85 \\
MD 51ne (G) & 22.80 & 27.52 & 54.88 & 4.40 & 0.37 & 0.17 & 1.27 \\
MD 51ne (Y) & 23.21 & 27.37 & 54.99 & 3.33 & 0.41 & 0.15 & 1.24 \\
SA30 (P) & 23.94 & 28.90 & 54.42 & 3.40 & 0.41 & 0.16 & 1.24 \\
SG 747 (G) & 23.26 & 30.16 & 53.82 & 4.28 & 0.43 & 0.17 & 1.16 \\
SG 747 (Y) & 25.42 & 28.28 & 53.84 & 4.52 & 0.45 & 0.14 & 1.19 \\
LSD & 1.62 & 1.61 & 0.20 & 0.08 & 0.02 & 0.007 & 0.12 \\
\hline D & P & B & Cu & Fe & Mn & Ni & Zn \\
\hline DES 119 (G) & 0.91 & 13.55 & 11.18 & 77.76 & 17.45 & 3.44 & 46.13 \\
DES 119 (Y) & 0.77 & 11.57 & 9.57 & 64.63 & 14.10 & 2.23 & 44.93 \\
DP 5690 (G) & 0.87 & 12.40 & 8.52 & 53.33 & 15.79 & 4.43 & 35.48 \\
DP 5690 (Y) & 0.73 & 10.92 & 8.38 & 55.04 & 12.45 & 2.93 & 36.03 \\
MD 51ne (G) & 0.84 & 12.00 & 11.73 & 68.91 & 16.93 & 4.34 & 45.68 \\
MD 51ne (Y) & 0.74 & 12.37 & 7.57 & 55.09 & 14.50 & 1.79 & 45.53 \\
SA30 (P) & 0.76 & 12.02 & 8.95 & 55.47 & 14.13 & 2.62 & 41.50 \\
SG 747 (G) & 0.80 & 12.90 & 9.30 & 67.10 & 16.95 & 3.40 & 44.44 \\
SG 747 (Y) & 0.73 & 12.72 & 9.60 & 57.02 & 13.63 & 2.27 & 43.60 \\
\hline LSD & 0.02 & 0.36 & 0.40 & 1.12 & 0.38 & 0.22 & 0.81 \\
\hline
\end{tabular}

${ }^{\text {a}}$ Fisher's protected least significant difference (LSD) test at the $5 \%$ level of significance.

compared with their equivalent $\mathrm{Y}$ lines, although the difference in $\mathrm{B}$ content between SG 747 (G) and SG 747 (Y) was not significantly different. The content of $\mathrm{Cu}$ and Fe were the highest in both DES $119(\mathrm{G})$ and MD 51ne (G). For Mn, SG 747 (G) is higher than MD 51ne (G); for Ni, DP $5690(\mathrm{G})$ was higher than MD 51ne (G), and SG $747(G)$ is equivalent to DES $119(\mathrm{G})$; for Zn, MD 51ne $(\mathrm{Y})$ is equivalent to MD 51ne $(\mathrm{G})$ and is among the highest levels. With few exceptions, the lower concentration of these nutrients $(\mathrm{Cu}, \mathrm{Fe}, \mathrm{Mn}, \mathrm{Ni}$, and $\mathrm{Zn}$ ) was recorded in the yellow lines, including the parent line SA $30(\mathrm{P})$. The range of nutrient content in seed in 2014 was (\%) from 20.42 to 25.42 (24.5\% difference) for protein; 27.37 to 30.16 for oil (10.2\% difference); 53.82 to 56.85 for C (5.6\% difference); 3.2 to 4.70 for $\mathrm{N}$ ( $47 \%$ difference); 0.11 to 0.17 for $\mathrm{Ca}$ (55\% difference); 0.85 to 1.27 for K ( $49 \%$ difference); 0.73 to 0.91 for $\mathrm{P}$ ( $25 \%$ difference) and (mg. $\left.\mathrm{kg}^{-1}\right)$ from 10.92 to 13.55 for B (24\% difference); 53.33 to 77.76 
for Fe (46\% difference); 12.45 to 17.45 for Mn (40\% difference); 1.79 to 4.43 for $\mathrm{Ni}$ (47\% difference); and 35.48 to 46.13 for $\mathrm{Zn}$ (30\% difference).

In 2015, protein content was higher in all G lines than Y lines (Table 3). Oil content was also significantly higher in all $\mathrm{G}$ lines and lower in $\mathrm{Y}$ lines. The parent line SA 30 (P) had also lower oil content. The content of $\mathrm{C}$ and $\mathrm{N}$ was higher in all $\mathrm{G}$ lines than in $\mathrm{Y}$ lines, and the lowest $\mathrm{N}$ content was recorded in SA 30 (P). No clear trend was observed for $S$ and $K$, but $S$ content was higher in $D P$ 5690 (Y), SG 747 (Y), and MD 51ne (Y), and SA 30 (P) than their equivalent G lines. Calcium had no clear trend as well, but Ca content was higher in DES119 $(\mathrm{G})$, MD51ne (G), MD51ne(Y), SA30 (P), and SG747 (G) than the rest of the lines. The content of $\mathrm{P}, \mathrm{B}, \mathrm{Cu}$, and $\mathrm{Fe}$ was higher in $\mathrm{G}$ lines than their equivalent $\mathrm{Y}$ lines and higher than SA 30 (P). A similar trend was noticed for Mn, except for SG 747 (G) and SG 747 (Y), where both lines did not show any significant differences

Table 3. Effect of leaf color (green, G; and yellow, Y) on seed composition (protein and oil expressed as \%), and nutrients ( $, C, S, K, P$, and Ca were expressed as \%; $, \mathrm{Cu}, \mathrm{Fe}$, $\mathrm{Mn}, \mathrm{Ni}$, and $\mathrm{Zn}$ were expressed as $\mathrm{mg} \cdot \mathrm{kg}^{-1}$ ) in four sets of near-isogenic cotton lines and their virescent parent grown in Stoneville, MS in 2015.

\begin{tabular}{cccccccc}
\hline Line & Protein & Oil & C & N & S & Ca & K \\
\hline DES 119 (G) & 27.23 & 31.70 & 57.40 & 4.23 & 0.44 & 0.15 & 1.20 \\
DES 119 (Y) & 23.30 & 25.70 & 51.67 & 3.07 & 0.37 & 0.12 & 1.07 \\
DP 5690 (G) & 26.87 & 30.53 & 54.50 & 4.07 & 0.42 & 0.13 & 1.13 \\
DP 5690 (Y) & 23.43 & 26.60 & 51.93 & 3.30 & 0.49 & 0.10 & 1.17 \\
MD 51ne (G) & 25.43 & 26.47 & 56.43 & 4.00 & 0.43 & 0.14 & 1.04 \\
MD 51ne (Y) & 21.47 & 24.40 & 50.63 & 2.67 & 0.45 & 0.14 & 1.07 \\
SA30 (P) & 23.10 & 24.90 & 51.77 & 2.50 & 0.45 & 0.16 & 1.04 \\
SG 747 (G) & 27.27 & 29.27 & 55.43 & 4.47 & 0.43 & 0.15 & 1.08 \\
SG 747 (Y) & 25.07 & 26.30 & 51.07 & 3.40 & 0.47 & 0.13 & 1.05 \\
LSD & 0.80 & 0.67 & 0.62 & 0.25 & 0.02 & 0.0047 & 0.03 \\
\hline & P & B & Cu & Fe & Mn & Ni & Zn \\
\hline DES 119 (G) & 0.82 & 11.73 & 10.73 & 64.07 & 15.17 & 3.27 & 45.57 \\
DES 119 (Y) & 0.68 & 9.14 & 9.63 & 55.47 & 12.67 & 2.33 & 44.87 \\
DP 5690 (G) & 0.72 & 11.43 & 11.63 & 44.97 & 12.80 & 3.17 & 33.23 \\
DP 5690 (Y) & 0.55 & 10.00 & 9.61 & 42.77 & 10.80 & 4.03 & 35.80 \\
MD 51ne (G) & 0.70 & 11.73 & 10.80 & 52.73 & 13.37 & 4.01 & 47.27 \\
MD 51ne (Y) & 0.54 & 9.43 & 8.53 & 45.13 & 10.93 & 3.80 & 40.77 \\
SA30 (P) & 0.51 & 10.23 & 9.13 & 43.80 & 12.20 & 2.97 & 37.93 \\
SG 747 (G) & 0.70 & 11.90 & 10.60 & 55.40 & 13.13 & 3.20 & 43.13 \\
SG 747 (Y) & 0.55 & 10.37 & 8.27 & 47.73 & 13.23 & 2.13 & 42.77 \\
LSD & 0.02 & 0.42 & 0.40 & 2.11 & 0.48 & 0.25 & 0.99 \\
\hline
\end{tabular}

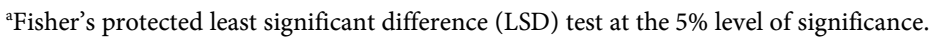


for Mn. Nutrients $\mathrm{Ni}$ and $\mathrm{Zn}$ did not show a clear trend between $\mathrm{G}$ and $\mathrm{Y}$ lines, but Ni content was higher in DES 119 (G), DP 5690 (G), DP 5690 (Y), MD 51ne $(\mathrm{G})$, MD 51ne (Y), SG $747(\mathrm{G})$ than the rest of the $Y$ lines [bearing in mind that there are differences in Ni content among these lines; for example] [highest levels of Ni content was recorded in DP $5690(\mathrm{Y})$ and MD 51ne (G)] [next was MD 51ne (Y)] [and last set has DES 119 (G)] [DP 5690 (G)] [and SG $747(\mathrm{G})$ ]. Zinc content was higher in DES $119(\mathrm{G})$, DES 119 (Y), MD 51ne (G), SG 747 $(\mathrm{G})$, and SG $747(\mathrm{Y})$ than the rest of $Y$ lines. Generally, with few exceptions, the content of $\mathrm{C}, \mathrm{N}, \mathrm{P}, \mathrm{B}, \mathrm{Cu}, \mathrm{Fe}$, and $\mathrm{Mn}$ was higher in $\mathrm{G}$ lines than their counterpart $\mathrm{Y}$ lines, especially in 2015. The nutrient content in seed (\%) in 2015 ranged from 21.47 to 27.27 for protein ( $27 \%$ difference); 24.40 to 31.70 for oil ( $30 \%$ difference); 50.63 to 57.40 for $\mathrm{C}$ ( $13 \%$ difference); 2.50 to 4.47 for $\mathrm{N}$ ( $40 \%$ difference); 0.37 to 0.49 for S (32\% difference); 0.10 to 0.16 for $\mathrm{Ca} 60 ; 1.04$ to 1.2 for $\mathrm{K}$ (15\% difference); 0.51 to 0.82 for P (37\% difference); and ( $\left.\mathrm{mg}^{\circ} \mathrm{kg}^{-1}\right) 9.14$ to 11.90 for B (30\% difference); 42.77 to 64.07 for Fe (50\% difference); 8.27 to 11.63 for $\mathrm{Cu}$ (41\% difference); 10.80 to 15.17 for $\mathrm{Mn}$ (40\% difference); 2.13 to 4.03 for $\mathrm{Ni}$ (88\% difference); and 33.23 to 47.27 for $\mathrm{Zn}$ (42\% difference).

\subsection{Correlations between Nutrients}

Correlation between nutrients in 2014 showed that there was no correlation between protein and nutrients and between oil and nutrients (Table 4). There were positive correlations between $\mathrm{Ca}$ with $\mathrm{P}, \mathrm{B}, \mathrm{Cu}, \mathrm{Fe}, \mathrm{Mn}$, and $\mathrm{Zn}$. Potassium positively correlated with $\mathrm{B}$. The following positive correlations were also found: between $\mathrm{P}$ and $\mathrm{C}, \mathrm{N}, \mathrm{B}, \mathrm{Cu}, \mathrm{Fe}, \mathrm{Mn}$, and $\mathrm{Ni}$; between $\mathrm{C}$ and $\mathrm{Ni}$; between $\mathrm{N}$ and $\mathrm{B}$, $\mathrm{Cu}, \mathrm{Fe}, \mathrm{Mn}$, and $\mathrm{Ni}$; between $\mathrm{S}$ and $\mathrm{Fe}$ and $\mathrm{Zn}$; between $\mathrm{B}$ and $\mathrm{Fe}$ and $\mathrm{Mn}$; between $\mathrm{Cu}$ and $\mathrm{Fe}, \mathrm{Mn}, \mathrm{Ni}, \mathrm{Zn}$; between $\mathrm{Fe}$ and $\mathrm{Mn}$ and $\mathrm{Zn}$; between $\mathrm{Mn}$ and $\mathrm{Ni}$ and $\mathrm{Zn}$. The pattern of correlation in 2015 was different from those of 2014. For example, both protein and oil positively correlated with $\mathrm{P}, \mathrm{C}, \mathrm{N}, \mathrm{B}, \mathrm{Cu}, \mathrm{Fe}$, and Mn in 2015 (Table 5), but this did not occur in 2014, where no correlation occurred between protein or oil with nutrients. Protein and oil were positively correlated. Oil was positively correlated with $\mathrm{K}$. There was a positive correlation between Ca and C in 2015. Potassium positively correlated with B in 2014.

Phosphorus positively correlated with C, N, B, Cu, Fe, and $\mathrm{Mn}$ in 2015, but also correlated with $\mathrm{Mn}$ in 2014. Carbon was positively correlated with $\mathrm{N}, \mathrm{B}, \mathrm{Cu}$, $\mathrm{Fe}$, and $\mathrm{Mn}$ in 2015, differing from those of 2014 where positive correlation only occurred with Ni. Nitrogen correlation with nutrients in 2015 was similar to those in 2014, except for $\mathrm{Ni}$ where the correlation occurred in 2014. A positive correlation occurred between $\mathrm{S}$ and $\mathrm{Ni}$ in 2015, differing from those occurred between $\mathrm{S}$ and $\mathrm{Fe}$ and $\mathrm{Zn}$ in 2014. Boron positively correlated with $\mathrm{Fe}$ and $\mathrm{Mn}$ in 2014 and 2015, but was also correlated with $\mathrm{Cu}$ in 2015. Copper positively correlated with Fe only in 2015, differing from those in 2014 where $\mathrm{Cu}$ was positively correlated with $\mathrm{Fe}, \mathrm{Mn}, \mathrm{Ni}$, and $\mathrm{Zn}$. Iron positively correlated with $\mathrm{Mn}$ and $\mathrm{Zn}$, similar to those in 2014; and Mn positively correlated with $\mathrm{Zn}$, similar to that in 2014, but different in that Mn positively correlated with Ni in 2014. 
Table 4. Pearson Correlation Coefficients ( $P$ and $R$ values) between seed nutrients in four sets of near-isogenic cotton lines expressing green or yellow leaf color and their virescent parent grown in Stoneville, MS in 2014.

\begin{tabular}{|c|c|c|c|c|c|c|c|c|c|c|c|c|c|c|}
\hline & & Protein & Oil & $\mathrm{Ca}$ & K & $\mathrm{P}$ & C & $\mathrm{N}$ & S & B & $\mathrm{Cu}$ & $\mathrm{Fe}$ & $\mathrm{Mn}$ & $\mathrm{Ni}$ \\
\hline \multirow{2}{*}{ Oil } & $R$ & 0.262 & & & & & & & & & & & & \\
\hline & $P$ & 0.186 & & & & & & & & & & & & \\
\hline \multirow{2}{*}{$\mathrm{Ca}$} & $R$ & 0.119 & -0.108 & & & & & & & & & & & \\
\hline & $P$ & 0.554 & 0.591 & & & & & & & & & & & \\
\hline \multirow{2}{*}{$\mathrm{K}$} & $R$ & 0.118 & 0.307 & 0.342 & & & & & & & & & & \\
\hline & $P$ & 0.559 & 0.119 & 0.081 & & & & & & & & & & \\
\hline \multirow{2}{*}{$\mathrm{P}$} & $R$ & -0.185 & 0.003 & 0.402 & 0.366 & & & & & & & & & \\
\hline & $P$ & 0.355 & 0.987 & 0.037 & 0.069 & & & & & & & & & \\
\hline \multirow{2}{*}{$\mathrm{C}$} & $R$ & -0.215 & 0.095 & -0.209 & 0.161 & 0.493 & & & & & & & & \\
\hline & $P$ & 0.281 & 0.636 & 0.296 & 0.423 & 0.009 & & & & & & & & \\
\hline \multirow{2}{*}{$\mathrm{N}$} & $R$ & -0.038 & 0.112 & 0.217 & 0.314 & 0.554 & 0.257 & & & & & & & \\
\hline & $P$ & 0.851 & 0.578 & 0.278 & 0.111 & 0.003 & 0.195 & & & & & & & \\
\hline \multirow{2}{*}{ S } & $R$ & -0.132 & 0.051 & 0.164 & 0.098 & 0.068 & -0.174 & 0.255 & & & & & & \\
\hline & $P$ & 0.519 & 0.805 & 0.424 & 0.634 & 0.743 & 0.397 & 0.209 & & & & & & \\
\hline \multirow{2}{*}{$\mathrm{B}$} & $R$ & 0.139 & 0.232 & 0.446 & 0.418 & 0.519 & -0.057 & 0.454 & 0.376 & & & & & \\
\hline & $P$ & 0.490 & 0.244 & 0.020 & 0.030 & 0.006 & 0.779 & 0.018 & 0.058 & & & & & \\
\hline \multirow{2}{*}{$\mathrm{Cu}$} & $R$ & -0.058 & -0.047 & 0.411 & 0.245 & 0.559 & -0.038 & 0.538 & 0.133 & 0.345 & & & & \\
\hline & $P$ & 0.773 & 0.817 & 0.033 & 0.219 & 0.002 & 0.852 & 0.004 & 0.518 & 0.078 & & & & \\
\hline \multirow{2}{*}{$\mathrm{Fe}$} & $R$ & -0.253 & 0.070 & 0.503 & 0.179 & 0.573 & -0.079 & 0.427 & 0.404 & 0.412 & 0.741 & & & \\
\hline & $P$ & 0.202 & 0.729 & 0.008 & 0.371 & 0.002 & 0.695 & 0.026 & 0.041 & 0.033 & $<0.0001$ & & & \\
\hline \multirow{2}{*}{$\mathrm{Mn}$} & $R$ & -0.059 & 0.117 & 0.705 & 0.374 & 0.752 & 0.173 & 0.553 & 0.108 & 0.567 & 0.569 & 0.731 & & \\
\hline & $P$ & 0.769 & 0.562 & $<0.0001$ & 0.055 & $<0.0001$ & 0.390 & 0.003 & 0.599 & 0.002 & 0.002 & $<0.0001$ & & \\
\hline \multirow{2}{*}{$\mathrm{Ni}$} & $R$ & 0.016 & 0.162 & 0.193 & 0.035 & 0.667 & 0.445 & 0.460 & -0.367 & 0.099 & 0.420 & 0.262 & 0.58 & \\
\hline & $P$ & 0.935 & 0.419 & 0.335 & 0.863 & $<0.0001$ & 0.020 & 0.016 & 0.066 & 0.622 & 0.029 & 0.187 & 0.002 & \\
\hline \multirow{2}{*}{$\mathrm{Zn}$} & $R$ & -0.057 & -0.207 & 0.570 & 0.343 & 0.130 & -0.346 & 0.186 & 0.514 & 0.349 & 0.480 & 0.632 & 0.446 & -0.258 \\
\hline & $P$ & 0.776 & 0.301 & 0.002 & 0.080 & 0.517 & 0.077 & 0.354 & 0.007 & 0.074 & 0.011 & $<0.0001$ & 0.020 & 0.194 \\
\hline
\end{tabular}

Table 5. Pearson Correlation Coefficients ( $P$ and $R$ values) between seed nutrients in four sets of near-isogenic cotton lines expressing green or yellow leaf color and their virescent parent grown in Stoneville, MS in 2015.

\begin{tabular}{|c|c|c|c|c|c|c|c|c|c|c|c|c|c|c|}
\hline & & Protein & Oil & $\mathrm{Ca}$ & K & $\mathrm{P}$ & C & $\mathrm{N}$ & S & B & $\mathrm{Cu}$ & $\mathrm{Fe}$ & $\mathrm{Mn}$ & $\mathrm{Ni}$ \\
\hline \multirow{2}{*}{ Oil } & $R$ & 0.632 & & & & & & & & & & & & \\
\hline & $P$ & 0.0004 & & & & & & & & & & & & \\
\hline \multirow{2}{*}{$\mathrm{Ca}$} & $R$ & 0.254 & 0.083 & & & & & & & & & & & \\
\hline & $P$ & 0.202 & 0.680 & & & & & & & & & & & \\
\hline \multirow{2}{*}{ K } & $R$ & 0.203 & 0.467 & -0.126 & & & & & & & & & & \\
\hline & $P$ & 0.311 & 0.014 & 0.532 & & & & & & & & & & \\
\hline
\end{tabular}


Continued

\begin{tabular}{|c|c|c|c|c|c|c|c|c|c|c|c|c|c|c|}
\hline \multirow{2}{*}{$\mathrm{P}$} & $R$ & 0.669 & 0.760 & 0.219 & 0.343 & & & & & & & & & \\
\hline & $P$ & $<0.0001$ & $<0.0001$ & 0.273 & 0.080 & & & & & & & & & \\
\hline \multirow{2}{*}{ C } & $R$ & 0.650 & 0.642 & 0.397 & 0.332 & 0.758 & & & & & & & & \\
\hline & $P$ & $<0.0001$ & $<0.0001$ & 0.040 & 0.090 & $<0.0001$ & & & & & & & & \\
\hline \multirow{2}{*}{$\mathrm{N}$} & $R$ & 0.655 & 0.675 & 0.071 & 0.226 & 0.637 & 0.727 & & & & & & & \\
\hline & $P$ & $<0.0001$ & $<0.0001$ & 0.724 & 0.258 & $<0.0001$ & $<0.0001$ & & & & & & & \\
\hline \multirow{2}{*}{$S$} & $R$ & -0.019 & -0.036 & -0.204 & 0.039 & -0.361 & -0.153 & -0.153 & & & & & & \\
\hline & $P$ & 0.924 & 0.860 & 0.308 & 0.846 & 0.065 & 0.445 & 0.448 & & & & & & \\
\hline \multirow{2}{*}{ B } & $R$ & 0.696 & 0.593 & 0.333 & 0.120 & 0.566 & 0.808 & 0.696 & -0.005 & & & & & \\
\hline & $P$ & $<0.0001$ & 0.001 & 0.090 & 0.550 & 0.002 & $<0.0001$ & $<0.0001$ & 0.979 & & & & & \\
\hline \multirow{2}{*}{$\mathrm{Cu}$} & $R$ & 0.559 & 0.647 & 0.142 & 0.243 & 0.691 & 0.757 & 0.543 & -0.238 & 0.678 & & & & \\
\hline & $P$ & 0.002 & $<0.0001$ & 0.480 & 0.222 & $<0.0001$ & $<0.0001$ & 0.003 & 0.232 & $<0.0001$ & & & & \\
\hline \multirow{2}{*}{$\mathrm{Fe}$} & $R$ & 0.447 & 0.458 & 0.290 & 0.136 & 0.668 & 0.657 & 0.453 & -0.211 & 0.415 & 0.373 & & & \\
\hline & $P$ & 0.019 & 0.016 & 0.142 & 0.500 & $<0.0001$ & $<0.0001$ & 0.018 & 0.290 & 0.031 & 0.056 & & & \\
\hline \multirow{2}{*}{ Mn } & $R$ & 0.569 & 0.611 & 0.307 & 0.143 & 0.680 & 0.524 & 0.580 & -0.195 & 0.506 & 0.293 & 0.546 & & \\
\hline & $P$ & 0.002 & 0.001 & 0.119 & 0.475 & $<0.0001$ & 0.005 & 0.002 & 0.331 & 0.007 & 0.138 & 0.003 & & \\
\hline \multirow{2}{*}{$\mathrm{Ni}$} & $R$ & -0.114 & 0.056 & -0.080 & 0.270 & -0.023 & 0.256 & 0.045 & 0.449 & 0.148 & 0.193 & -0.106 & -0.228 & \\
\hline & $P$ & 0.572 & 0.780 & 0.692 & 0.173 & 0.910 & 0.198 & 0.823 & 0.019 & 0.461 & 0.335 & 0.599 & 0.254 & \\
\hline \multirow{2}{*}{$\mathrm{Zn}$} & $R$ & 0.168 & -0.060 & 0.321 & -0.169 & 0.315 & 0.341 & 0.233 & -0.218 & 0.202 & -0.067 & 0.680 & 0.448 & -0.107 \\
\hline & $P$ & 0.403 & 0.766 & 0.103 & 0.401 & 0.110 & 0.082 & 0.243 & 0.276 & 0.313 & 0.741 & $<0.0001$ & 0.019 & 0.597 \\
\hline
\end{tabular}

\section{Discussion}

The non-significant effect of line or year by line interaction for protein and $\mathrm{K}$ indicated that year and line by year interaction did not change the trend and response of these constituents, and the trend and response of these nutrients were similar in each year. This was the opposite for $\mathrm{N}, \mathrm{C}, \mathrm{P}, \mathrm{B}, \mathrm{Cu}, \mathrm{Fe}, \mathrm{Mn}$ where these constituents were significantly influenced by year, line, and their interaction, and their responses to the environmental conditions in each year were significant. The different responses of these constituents in each year could be due to the different environmental factors such as temperature (Figure 1) and the sensitivity of nutrients to temperature as the experiment was irrigated. It is worth to notice that although some nutrients such as oil and Ca were affected by year and line, they were not significantly influenced by their interaction, and this may reflect the level of sensitivity and stability of these constituents with the environmental conditions.

The higher oil content in some G lines in 2014 and in almost all G lines in 2015 than the $Y$ lines indicated that the G lines showed a higher ability to accumulate more oil in seeds, and this may be due to higher photosynthesis capacity and higher rates of $\mathrm{C}$ and $\mathrm{N}$ metabolism, leading to higher oil synthesis. This explanation can be supported by a higher content of seed C and N in G lines than 
in Y lines, especially in 2015 where growth conditions were more favorable for some nutrient uptake, assimilation, and protein and oil production. In addition, most nutrient levels, especially in 2015, were higher in $G$ lines than in $Y$ lines. These nutrients, including $\mathrm{N}, \mathrm{P}, \mathrm{K}, \mathrm{C}, \mathrm{P}, \mathrm{B}, \mathrm{Cu}, \mathrm{Fe}$, and $\mathrm{Zn}$, were previously shown to be related to protein and oil in cotton and other species. For example, others studied the effects of $\mathrm{K}$ fertilization $\left(0.0\right.$ and $57.1 \mathrm{~kg}$ of $\left.\mathrm{K}_{2} \mathrm{O} \cdot \mathrm{ha}{ }^{-1}\right)$, foliar $\mathrm{Zn}$ application $\left(0.0\right.$ and $\left.60 \mathrm{mg} \cdot \mathrm{l}^{-1} \mathrm{Zn}\right)$, and $\mathrm{P}\left(0,600,1200\right.$ and $1800 \mathrm{mg} \cdot \mathrm{l}^{-1}$ of $\mathrm{P}_{2} \mathrm{O}_{5}$ ) on cottonseed yield and seed nutrition [52]. They found that the application of $\mathrm{K}, \mathrm{Zn}$, and $\mathrm{P}$ increased cottonseed yield, seed oil content, and seed oil and protein production (oil and protein.ha ${ }^{-1}$ ). In recent research [35] where these NIL sets were compared with the obsolete parent SA30 for growth rates, yields, and fiber quality, it was found that incorporating the $V_{1} V_{1}$ allele in modern lines led to higher yield in modern lines in spite of their yellow leaf color trait, indicating that these modern lines were bred for higher yields. This was supported by the fact that the boll yields and the plot weight measurements in yellow NILs was essentially a 2 -fold increase in yield in the yellow NILs derived from the SA30. For example, bolls/plant were: compared with SA 30 (5.87 bolls per plant), the yellow modern lines had: DES 119 (G) (14.50) and DES 119 (Y) (13.27); DP $5690(\mathrm{G})$ (12.52) and DP $5690(\mathrm{Y})$ 14.73); MD 51ne (G) (13.37) and MD 51ne (Y) (11.82); SG 747 (G) (14.21) and SG 747 (Y) (13.52). Detailed yield and growth will be published elsewhere [35]. It was suggested that further molecular/biochemical characterization and comparisons of transcriptomes of the SA30 and the NILs research may explain cellular mechanisms and identify gene(s) controlling the increased reproductive structure yields [35]. The similar pattern between SA 30 and yellow modern lines was found for lint weight (data not shown).

The role of $\mathrm{K}, \mathrm{Zn}$, and $\mathrm{P}$ in $\mathrm{CO}_{2}$ fixation, photosynthesis, carbon movement, electron transfer and energy production, and protein and carbon-related enzymes has been shown by others [52]-[56]. The role of $\mathrm{P}$ in photosynthesis process, carbon assimilation transport, and protein and oil has been previously shown [56] [57] [58]. Although our experiment did not suffer nutrient deficiency as soil had adequate soil nutrients, maintaining high content of these nutrients in leaves and seed would enhance seed quality traits, including protein and oil. Also, the role of $\mathrm{Mg}, \mathrm{S}$, and $\mathrm{B}$ were previously reported by others, who indicated that the application of $\mathrm{MgSO}_{4}(1 \%)$ at 60 days after seedling (DAS) with combination of $\mathrm{B}$ at $0.1 \%$ at 75 DAS resulted in higher number of flowers per plant, number of bolls per plant, average boll weight, seed cotton yield and seed yield [59]. It was suggested that the positive effects of $\mathrm{Mg}, \mathrm{S}$, and B were due to the increased metabolic activities, protein synthesis, and mobilization of photosynthates [60] [61]. In addition, most of micronutrients such as $\mathrm{Zn}, \mathrm{Fe}, \mathrm{Mn}$, $\mathrm{Cu}, \mathrm{B}$, and $\mathrm{Mg}$ are catalysts in enzymatic reactions, required for respiration, meristematic development, chlorophyll formation, photosynthesis, protein and oil synthesis, and gossypol, tannin and phenolic metabolism [58] [61] [62] [63]. The 
information on the effects of phenotype trait such as leaf color on cottonseed nutrition using near-isogenic lines is limited. Previous research, conducted in our laboratory, [34] studied the effects of fuzzy/linted and fuzzless/linted seed phenotypes on cottonseed protein, oil, and minerals in near-isogenic Gossypium hirsutum cotton lines under field conditions. They found that protein content was higher in fuzzy genotype lines, but oil was higher in fuzzless genotype lines as the relationship between protein and oil is inversely correlated [34]. In addition, it was found that $\mathrm{Ca}$ and $\mathrm{C}$ content were higher in fuzzless genotypes than fuzzy, but N, S, B, Fe, and Zn content were higher in fuzzy than in fuzzless lines [34]. They concluded that seed fiber involved with $\mathrm{N}$ and $\mathrm{C}$ metabolism, affecting protein and oil composition and the mobility of nutrients from leaves (source) to seed (sink). A greenhouse experiment, conducted on similar lines under irrigated and non-irrigated conditions, showed similar results and achieved similar conclusions [33].

The significant differences between $G$ lines and $Y$ lines and between lines for nutrient content in seed could be due to environmental conditions of each year (E), genotype $(\mathrm{G})$ differences, and $\mathrm{G} \times \mathrm{E}$ interactions. Some lines showed wide range of nutrient content compared with others. The response of nutrients in each year was different. Researchers screened 20 cotton genotypes for protein and oil and found that the frequency distribution showed normal distribution, and differences in protein and oil were significantly different among genotypes [64]. In addition, they reported that the relationship between protein and oil was inverse and complex. They suggested that these complex relationships are associated with genetics. Others analyzed the diversity of cottonseed protein and oil, and other seed quality components in the U.S. National Cotton Germplasm Collection [65]. They reported studies from nine genomes (one tetraploid and eight diploid), 33 species (five tetraploid and 28 diploid), and surveyed 2256 accessions. They found that oil content ranged from $8 \%$ to $27 \%$ and protein ranged from $10 \%$ to $36 \%$, and reported that most of the range values were present within G. hirsutum and G. barbadense, suggesting that the variability of cottonseed protein and oil can be introduced into current breeding programs from these two species. They reported that there has been only slight variability in oil and protein content of new cotton cultivars over the past 19 years as found by the High-Quality Regional Test category of the National Cotton Variety Tests. For example, the first 5 -year average was higher (20.2\% oil; $22.1 \%$ protein) than the most recent 5 years (19.7\% oil; $21.4 \%$ protein), indicating a decline. The slight decline and minor variation could be due to environmental effects and not genetics [66] [67]. The information here is useful for a breeding program to identify germplasm that can be used to select cotton varieties with high protein or oil content in cottonseeds.

A three-year experiment was conducted to investigate the genetic variability of seed oil content in 20 wild species, two cultivated species, and six perennial races of Gossypium arboreum cotton [68]. They found the mean seed oil content va- 
ried from $10.26 \%$ to $22.89 \%$ in 22 species of Gossypium and six races of $G$. arboreum, and the highest level of oil was recorded in $G$. lobatum followed by $G$. harknessii. Because they found that five wild species of Gossypium surpassed the best lines and G. arboreum for seed oil, they suggested crosses between lines of G. arboreum and wild species of Gossypium can be promising. They concluded that such information is beneficial for efficient breeding selection for new cotton genotypes with improved cottonseed oil with a broad genetic base. A study was conducted on genetic variability, heritability, genetic gain and correlations for cottonseed soil in eight $G$. hirsutum cultivars and found significant differences among the genotypes for seed oil, which ranged from $27.52 \%$ to $30.15 \%$, and a negative correlation was found between oil and yield [69]. Others evaluated oil content in $22 \mathrm{~F}_{6}$ cotton lines ( $G$. hirsutum) and found that there is genetic variability, and the overall mean oil content ranged between $23.52 \%$ and $24.51 \%$, and they are higher than those of the Brazilian cultivar BRS Aroeira that have oil content of $22.04 \%$ [70]. They also repeated that the analysis of variance in each environment showed differences between the oil contents of the 22 lines. For example, in three locations the variation in oil content between the lines ranged from $21.67 \%$ to $27.59 \%, 20.1 \%$ to $24.2 \%$, and $17.0 \%$ to $22.6 \%$, respectively. However, the variation between checks in the three locations was smaller; ranged from $22.93 \%$ to $25.93 \%, 20.4 \%$ to $21.3 \%$, and $19.4 \%$ to $19.8 \%$, respectively. They indicated that a wide range of variability between lines, and between lines and checks, and between environments may be due to $\mathrm{G} \times \mathrm{E}$ interactions [70]. Our research showed wide averages; for example, the averages across two years ranged from $24 \%$ to $27 \%$ for protein and $10 \%$ to $30 \%$ for oil, and similarly for nutrients such as $\mathrm{N}$, and minerals such as $\mathrm{P}, \mathrm{K}, \mathrm{B}, \mathrm{Fe}$, and Ni. It was concluded that the complex relationships between seed quality components and their variation, independently and in relation to each other, will provide a better tool to select parents for breeding programs for higher seed nutritional qualities [65]. They also reported that the development of cotton cultivars with genetic diversity and wide range of protein and oil will allow for basic studies in genetics, nutritional, and technological implications of protein and oil and their quality as cottonseed is a source of protein, oil, and minerals for human as food and livestock as feed. Growing the world population to nine billion by 2050 [71] will need efficient food production and maintaining high seed nutritional qualities.

Mapping and gene identification for the virescent gene $v 1$ has been recently found. In an experiment conducted on mapping and identification of the virescent gene $v 1$ in Upland cotton (Gossypium hirsutum), it was reported that young leaves of virescent mutants are yellow and gradually turn green as the plants reach maturity [37]. Mapping studies revealed a recessive gene ( $v 1)$ from a virescent mutant of Upland cotton was found and narrowed to an $84.1-\mathrm{Kb}$ region containing ten candidate genes. The $v 1$ gene from the $v 1$ mutant was mapped to chromosome D10, Gh_D10G0283/GhChlI, and is related to Chl synthesis and likely the cause of the gene for the virescent trait. The $v 1$ gene 
(GhChll) encodes the cotton Mg-chelatase I subunit (CHLI) and was identified as the candidate gene for the virescent mutation. The accumulation of a chlorophyll biosynthetic intermediate, Mg-protoporphyrin (one of the plastid signals affecting the transcription of nuclear genes encoding chloroplast proteins [72]. The GhChlI gene has two copies, Gh_A10G0282 and Gh_D10G0283, and the coding region of GhChII is 1269 bp in length, with three predicted exons and one non-synonymous nucleotide mutation (G1082A) in the third exon of Gh_D10G0283, with an amino acid substitution of arginine to lysine. GhChlI-silenced TM-1 plants exhibited a lower GhChlI expression level, a lower chlorophyll content, and the virescent phenotype. Analysis of upstream regulatory elements and expression levels of GhChlI showed that the expression of GhChII could be normal, and with the development of the true leaf, the increase in the Gh_A10G0282 could partially for the deficiency of Gh_D10G0283 in the $v 1$ mutant. Also, it was reported that although the protein sequence encoded by the third exon of GhChlI is highly conserved across diverse plant species, an amino acid substitution in conserved residues mainly resulted in leaf color changes in various species. Based on this, it was suggested that the mutation (G1082A) in the GhChII gene may lead to a functional defect of the GhCHLI subunit and consequently to the virescent phenotype in the $v 1$ mutant. Therefore, studying the $v 1$ gene will increase further understanding of the genetic basis of virescent mutants and the regulatory mechanisms associated with chloroplast development and chlorophyll biosynthesis; the GhChII mutation provides a tool to advance our understanding of the association between CHLI protein function and the chlorophyll biosynthesis pathway and impacts breeding programs [37]. In our research, modern yellow lines had higher lint yield than absolute yellow lines, indicating modern yellow lines contains in their genetic makeup some additional markers for higher-yielding trait; if this observation is exploited, it should advance our knowledge in developing higher-yielding cotton across other genotypes. Also, it was reported that leaf-color markers can be used to remove off-type plants in plant breeding [6]. This is because leaf-color mutations often result in abnormal chloroplast development and chlorophyll biosynthesis. This was supported by the results obtained by others [37] that the total chlorophyll content of the second leaf from the top of T582 was significantly lower (50\% lower than the wild type parent, TM-1). The similar observation was noticed for chloroplast number per cell and lamellar structures where the number was significantly lower in T582 compared with that of the wild type, concluding that the $v 1$ gene mutation disrupts the formation of thylakoids in the chloroplast, leading to chlorophyll accumulation [37].

It can be concluded that leaf-color mutants are effective tools to study chloroplast development and chlorophyl biosynthesis [73]; understanding the molecular mechanisms between mutations within GhChlI gene and GhCHLI protein function; linkage between the catalytic efficiency of Mg-chelatase and mutations within the GhChII gene; linkage and between the mutation (G1082A) and the 
interaction among the CHLI, CHLH, and CHLD subunits [37]; and contribute to the application of leaf-color markers in cotton breeding [6] [37]

The involvement of the $v 1$ gene in chloroplast development was also shown by others [73]. They worked on rice virescent-2 mutant ( $v 2)$, a temperature-sensitive mutant, and showed that the mutant develops chlorotic leaves at temperature $\left(20^{\circ} \mathrm{C}\right)$, but almost had normal green leaves at temperature $\left(30^{\circ} \mathrm{C}\right)$. This mutation is suggested to be responsible for plastid encoded proteins involved in photosynthesis and plastid transcriptional regulation during chloroplast differentiation; they also found that the translation of the plastid transcripts encoding the plastid transcription/translation apparatus was blocked at an early stage of chloroplast differentiation. They reported that the accumulation of transcripts of nuclear encoded photosynthetic genes was significantly suppressed in the mutant at later stages of chloroplast differentiation, but transcripts of genes accumulated at higher levels at later stages, concluding that the growth stage of plastid translation machinery of chloroplast differentiation is important for triggering the induction of nuclear-encoded chloroplast proteins at later stages. The accumulation of a chlorophyll biosynthetic intermediate, Mg-protoporphyrin [72].

Recently, using map-based gene cloning method [37], an improved bulked segregant analysis method was conducted in virus-induced gene silencing strategy for gene mapping to further fine-map the $v 1$ locus. The method was applied to a multiple recessive marker Texas 582 (T582 upland cotton. They identified unique genomic positions of mutant loci. They reported that the $v 1$ locus was mapped and one gene, GhCHLI, encodes one of the subunits of Mg-chelatase, was differentially down-regulated in T582 compared with TM-1. A point mutation occurred in the AAA+ conserved region of GhCHLI and led to an amino acid substitution. Suppression of its expression by virus-induced gene silencing strategy in TM-1 led to a yellow leaf phenotype. They reported that they identified the gene underlying the $v 1$ locus encoding the CHLI subunit of Mg-chelatase I. Mg-chelatase I contains CHLI, CHLD and CHLH subunits in dicot plants. They further reported that the three subunits, CHLI and CHLD, have a similar ATPase structure and an amino acid (AAA+ domain in the $\mathrm{N}$-terminus).

The positive correlations between nutrients in 2014 and 2015, especially between $\mathrm{C}, \mathrm{N}, \mathrm{P}$, and other nutrients including $\mathrm{B}, \mathrm{Fe}, \mathrm{Cu}$, and $\mathrm{Zn}$ were also previously reported by others on cotton and other species [38] [74]-[78]. The correlation between protein and nutrients and oil and nutrients that occurred in 2015 and not in 2014 could be due to the temperature differences between 2015 and 2014 as temperatures in 2015 were higher than in 2014 during the critical growing period (June-September). For example, the maximum temperatures in 2014 were $31.39^{\circ} \mathrm{C}, 31.15^{\circ} \mathrm{C}$, and $32.49^{\circ} \mathrm{C}$, and $31.28^{\circ} \mathrm{C}$, respectively in June, July, August, and September (Figure 1). The temperatures in 2015 were $32.63^{\circ} \mathrm{C}$, $34.10^{\circ} \mathrm{C}, 33.35^{\circ} \mathrm{C}, 33.0^{\circ} \mathrm{C}$, respectively in June, July, August, and September (Figure 1) (Mississippi State Extension 2018). It was found that temperature or 

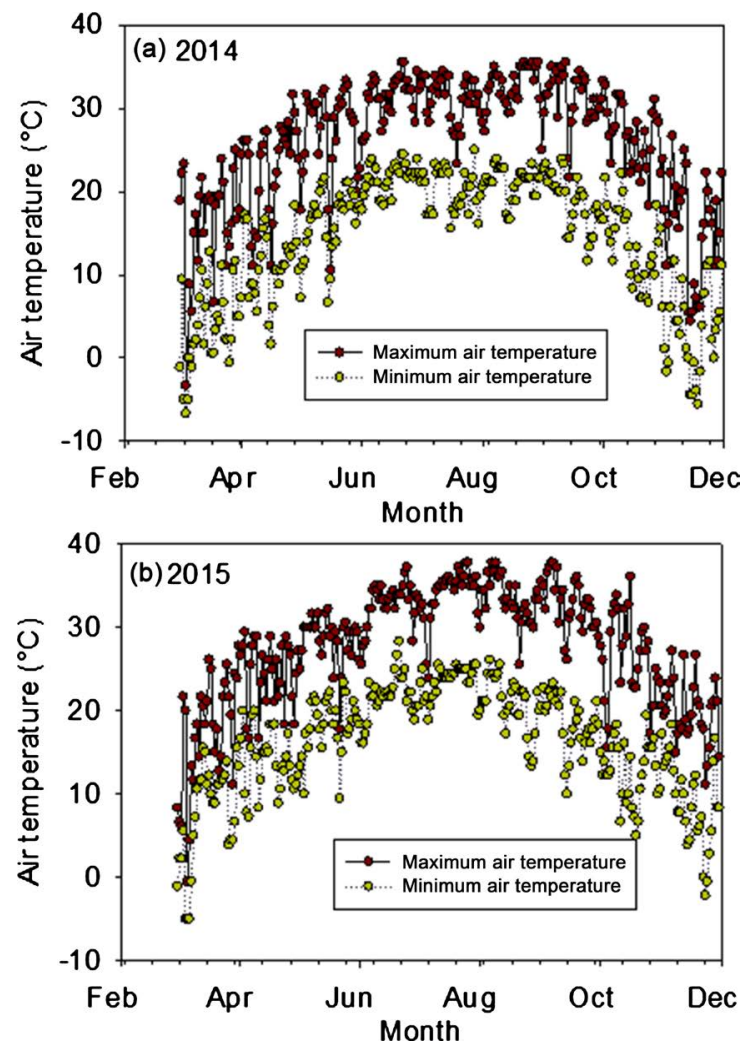

Figure 1. Air temperature $\left({ }^{\circ} \mathrm{C}\right)$ during the growing season in 2014 (a) and 2015 (b). The experiment was conducted in 2014 and 2015 in Stoneville MS. Source: Mississippi State University Extension (2018); http://extension.msstate.edu/agriculture/crops/cotton.

temperature differences between years can affect the accumulation and correlation between seed composition components in different species [38] [75] [76] [77] [78]. This could be due to temperature effects on the uptake rate of nutrients from the soil, and the movement of nutrients from leaves (source) to seed (sink) [33] [34]. They concluded that high temperatures during the growing season, and especially during the critical stages such as seed-fill, can alter seed composition. The inverse relationship between protein and oil was due to the genetically inherited trait between protein and oil [78]. The distribution of nutrients accumulation in seed in genotypes (Figure 2 and Figure 3) showed uniform and bimodal distribution an confirm the efficiency differences of genotypes in accumulating nutrients as previously reported [33].

\section{Conclusions}

The current research demonstrated that a phenotype trait such as leaf color can influence seed protein, oil, and mineral nutrition as the leaf color may be involved in photosynthesis and $\mathrm{N}$ and $\mathrm{C}$ metabolism. It appears that green leaf isogenic lines accumulate more nutrients than the yellow color lines, and this was clearly and consistently observed in 2015. Temperature differences between the growing seasons can affect the relationships between protein and oil, and between protein and oil and other nutrients. In our case, year of 2015 was warmer 

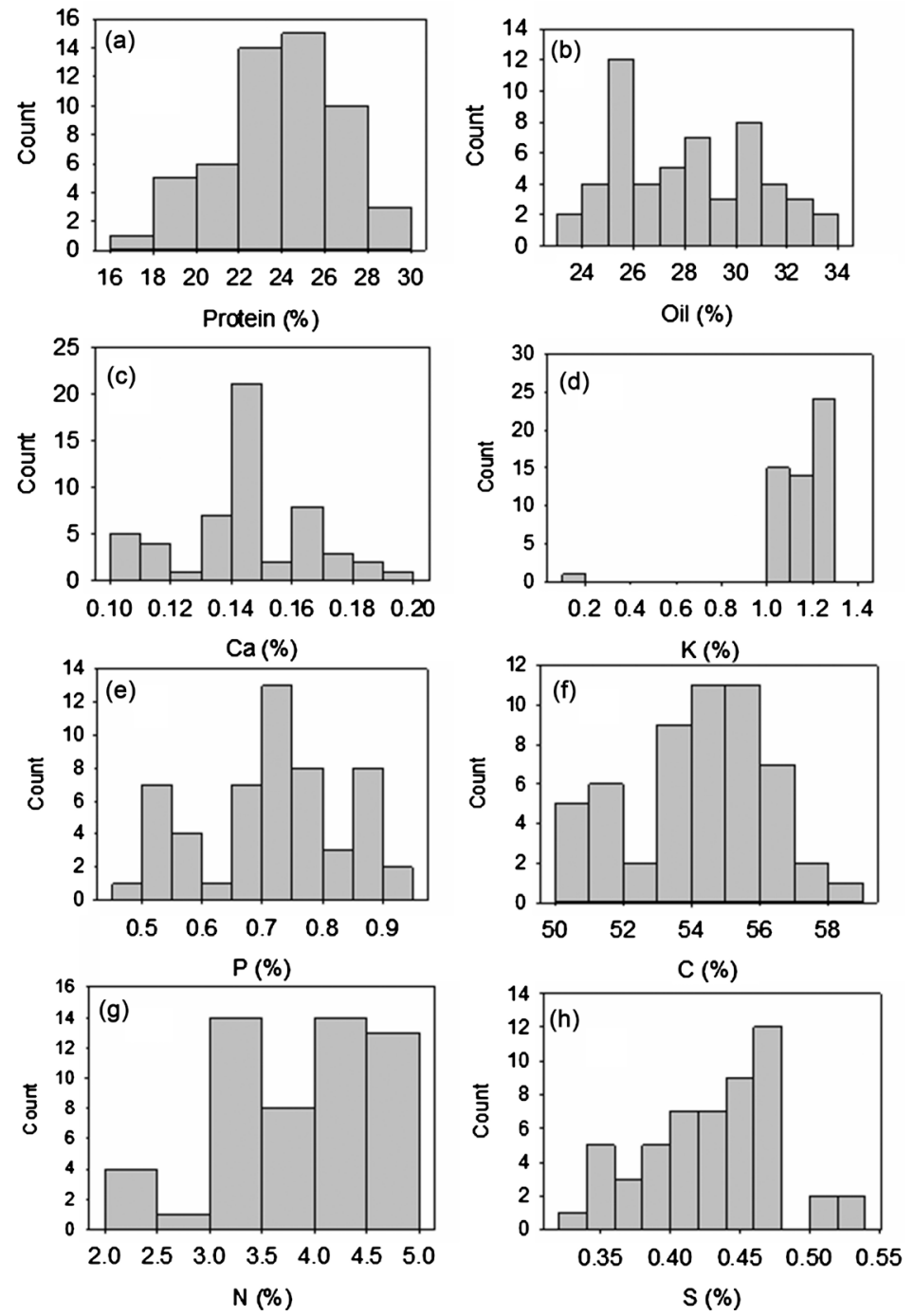

Figure 2. Distributions of seed protein, oil, Ca, K, P, C, N, and S (\%) ((a)-(h)) across years and lines in near-isogenic cotton lines expressing green or yellow leaf color and the virescent parent. The experiment was conducted in Stoneville, MS in 2014 and 2015.
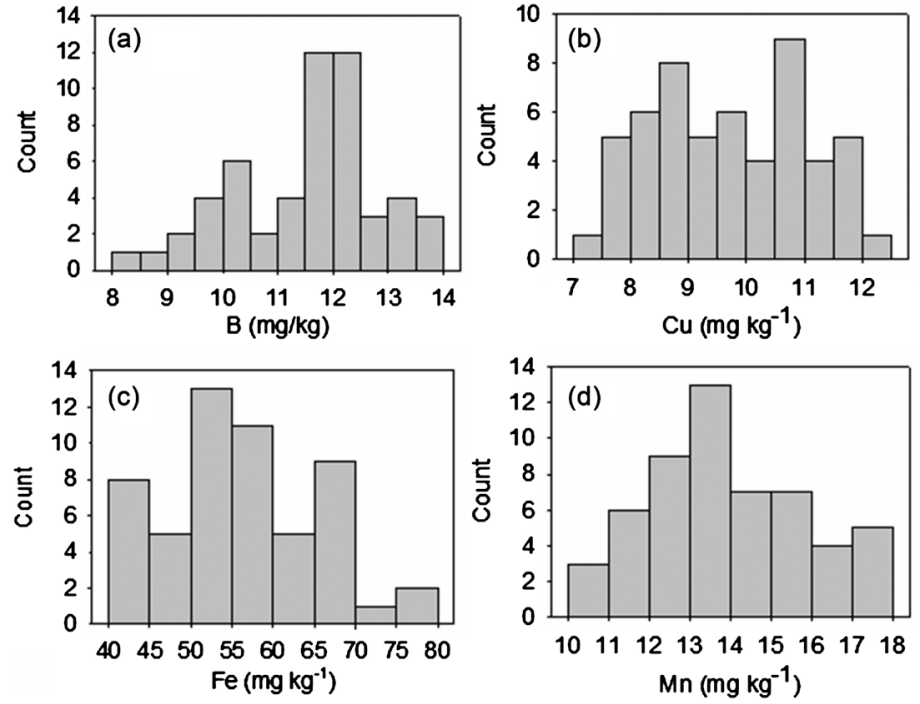

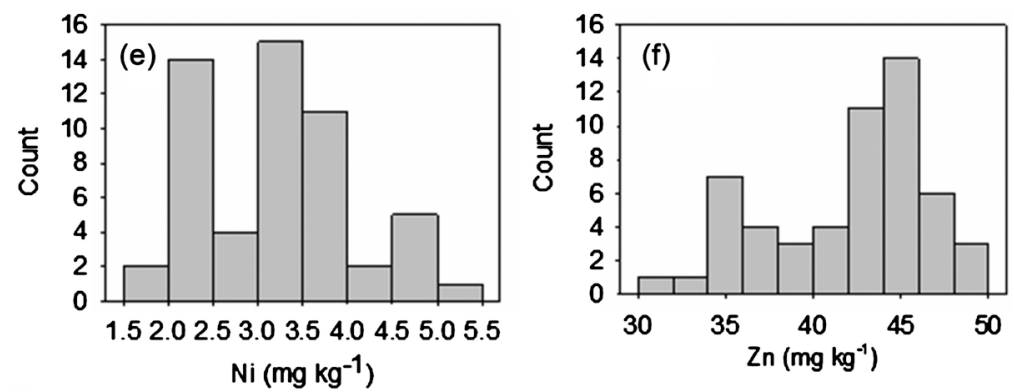

Figure 3. Distributions of seed $\mathrm{B}, \mathrm{Cu}, \mathrm{Fe}, \mathrm{Mn}, \mathrm{Ni}$, and $\mathrm{Zn}\left(\mathrm{mg}^{\mathrm{kg}} \mathrm{kg}^{-1}\right)((\mathrm{a})-(\mathrm{f}))$ across years and lines in near-isogenic cotton lines expressing green or yellow leaf color and the virescent parent. The experiment was conducted in Stoneville, MS in 2014 and 2015.

than 2014, and this led to the fact that the correlation among minerals and between protein and minerals and between oil and minerals was different. The correlation between protein and nutrients and between oil and nutrients was different in each year, depending on the temperature of each year, reflecting the significant influence of environment effects on nutrient accumulation on the seed. The information in this research will benefit breeders in that both phenotype traits such as leaf color and environmental factors such as heat can affect the relationships between nutrients, including seed composition and mineral nutrition. The wide range of seed protein, oil, and minerals in these lines, allowing for opportunities for breeders to select for higher nutritional qualities in seeds. Further research is needed to investigate the effects of leaf color on seed amino acids and carbohydrates in these near-isogenic lines.

\section{Acknowledgements}

Technical support provided by S. Mosley, K. Jordan, and R. Manning is appreciated. This work was funded by the U.S. Department of Agriculture, Agricultural Research Service Project 6066-21220-012-00D. Department of Agriculture. Mention of trade names or commercial products in this publication is solely for the purpose of providing specific information and does not imply recommendation or endorsement by the U. S. Department of Agriculture (USDA). USDA is an equal opportunity provider and employer.

\section{Author Contributions Statement}

NB contributed to the experimental design, analysis of seed composition and mineral nutrition, interpretation, and manuscript writing. RBT contributed to the planning, design, data interpretation, and writing. SRS contributed to the planning, design, data interpretation, and writing. WTM contributed to the physiology aspect of the project.

\section{Conflicts of Interest}

The authors declare that the research was conducted in the absence of any commercial or financial relationships that could be construed as a potential conflict of interest. 


\section{References}

[1] Yu, J.W., Yu, S.X., Fan, S.L., Song, M.Z., Zhai, H.H., Li, X.L., et al. (2012) Mapping Quantitative Trait Loci for Cotton Seed Oil, Protein and Gossypol Content in a Gossypium hirsutum $\times$ Gossypium barbadense Backcross Inbred Line Population. Euphytica, 187, 191-201. https://doi.org/10.1007/s10681-012-0630-3

[2] Cherry, J.P. (1983) Cottonseed Oil. Journal of American Oil Chemists Society, 60, 360-367. https://doi.org/10.1007/BF02543519

[3] Alford, B.B., Liepa, G.U. and Vanbeber, A.N. (1996) Cotton Seed Protein: What Does the Future Hold? Plant and Food Human Nutrition, 49, 1-11. https://doi.org/10.1007/BF01092517

[4] Liu, Q., Singh, S.P., Chapman, K. and Green, A.G. (2009) Bridging Traditional and Molecular Genetics in Modifying Cottonseed Oil. In: Paterson, A.H., Ed., Genetics and Genomics of Cotton, Plant Genetics and Genomics: Crops and Models, 3, Springer, New York, 353-382. https://doi.org/10.1007/978-0-387-70810-2_15

[5] Zhang, L. and Zeng, M. (2008) Proteins as Sources of Materials. In: Belgacem, M.N. and Gandini, A., Eds., Monomers, Polymers and Composites from Renewable Resources, Elsevier, Boston, 479-493. https://doi.org/10.1016/B978-0-08-045316-3.00023-5

[6] He, Z., Shankle, M., Zhang, H., Way, T.R., Tewolde, H. and Uchimiya, M. (2013) Mineral Composition of Cotton Seed Is Affected by Fertilization Management Practices. Agronomy Journal, 105, 341-350. https://doi.org/10.2134/agronj2012.0351

[7] Yang, H., Zhang, X., Chen, B., Meng, Y., Wang, Y., Zhao, W. and Zhou, Z. (2017) Integrated Management Strategies Increase Cotton Seed, Oil and Protein Production: The Key Role of Carbohydrate Metabolism. Frontiers in Plant Science, 8, 48. https://doi.org/10.3389/fpls.2017.00048

[8] Cherry, J.P. and Leffler, H.R. (1984) Seed. In: Kohel, R.J. and Lewis, C.F., Eds., Cotton, Agronomy Series No. 24, ASA, CSSA, SSSA, Madison, 511-569.

[9] O’Brien, R.D., Jones, L.A., King, C.C., Wakelyn, P.J. and Wan, P.J. (2005) Cotton Seed Oil. In: Shahidi, F., Ed., Bailey's Industrial Oil and Fat Products, 6th Edition, John Wiley \& Sons, Inc., Hoboken, 173-279. https://doi.org/10.1002/047167849X.bio022

[10] Dowd, M.K., Boykin, D.L., Meredith, W.R., Campbell, B.T., Bourland, F.M. and Gannaway, J.R. (2010) Fatty Acid Profiles of Cotton Seed Genotypes from the National Cotton Variety Trials. Journal of Cotton Science, 14, 64-73. http://www.cotton.org/journal/2010-14/2/upload/JCS14-64.pdf

[11] Zhou, X.R., Singh, S., Liu, Q. and Green, A. (2006) Combined Transgenic Expression of $\Delta 12$-Desaturase and $\Delta 12$-Epoxygenase in High Linoleic Acid Seeds to Increased Accumulation of Vernolic Acid. Functional Plant Biology, 33, 585-592. https://doi.org/10.1071/FP05297

[12] Shi, Y.H., Zhu, S.W., Mao, X.Z., Feng, J.X., Qin, Y.M., Zhang, L., Cheng, J., Wei, L.P., Wang, Z.Y. and Zhu, Y. (2006) Transcriptome Profiling, Molecular Biological, and Physiological Studies Reveal a Major Role for Ethylene in Cotton Fiber Cell Elongation. Plant Cell, 18, 651-664. https://doi.org/10.1105/tpc.105.040303

[13] Padmalatha, K.V., Patil, D.P., Kumar, K., Dhandapani, G., Kanakachari, M., Phanindra, M.L.V., et al. (2012) Functional Genomics of Fuzzless-Lintless Mutant of Gossypium hirsutum L. cv. MCU5 Reveal Key Genes and Pathways Involved in Cotton Fiber in Initiation and Elongation. BMC Genomics, 13, 624-638. https://doi.org/10.1186/1471-2164-13-624 
[14] Pettigrew, W.T. and Gerik, T.J. (2007) Cotton Leaf Photosynthesis and Carbon Metabolism. Advances in Agronomy, 94, 209-236. https://doi.org/10.1016/S0065-2113(06)94005-X

[15] Pettigrew, W.T. and Turley, R.B. (1998) Variation in Photosynthetic Components among Photosynthetically Diverse Cotton Genotypes. Photosynthesis Research, 56, 15-25. https://doi.org/10.1023/A:1005902028459

[16] Liu, Q., Singh, S. and Green, A. (2000) Genetic Modification of Cottonseed Oil Using Inverted-Repeat Gene-Silencing Techniques. Biochemical Society Transactions, 28, 927-929. https://doi.org/10.1042/0300-5127:0280927

[17] Liu, Q., Singh, S. and Green, A. (2002) High-Oleic and High-Stearic Cottonseed Oils: Nutritionally Improved Cooking Oils Developed Using Gene Silencing. Journal of American College of Nutrition, 21, 205-211. https://doi.org/10.1080/07315724.2002.10719267

[18] Stewart, J.M. (1975) Fiber Initiation on the Cotton Ovule (Gossypium hirsutum). American Journal of Botany, 62, 723-730. https://doi.org/10.2307/2442061

[19] Seagull, R.W. and Giavalis, S. (2004) Pre- and Post-Anthesis Application of Exogenous Hormones Alters Fiber Production in Gossypium hirsutum L. Cultivar Maxxa GTO. Journal of Cotton Science, 8, 105-111. https://www.cotton.org/journal/2004-08/2/upload/jcs08-105.pdf

[20] Stetina, S.R., Turley, R.B., Bellaloui, N. and Boykin, J.C. (2014) Yield and Fiber Quality of Five Pairs of Near-Isogenic Cotton (Gossypium hirsutum L.) Lines Expressing Fuzzless/Linted and Fuzzy/Linted Seed Phenotypes. Journal of Crop Improvement, 28, 680-699. https://doi.org/10.1080/15427528.2014.931901

[21] Wells, R. (2016) The Use of Obsolete and Modern Lines to Examine Advances in Yield and Dry Matter Partitioning. Journal of Cotton Science, 20, 246-252.

[22] Pettigrew, W.T. (2004) Cotton Genotypic Variation in the Photosynthetic Response to Irradiance. Photosynthetica, 42, 567-571. https://doi.org/10.1007/S11099-005-0014-1

[23] Du, X.B., Chen, B.L., Shen, T.Y., Zhang, Y.X. and Zhou, Z.G. (2015) Effect of Cropping System on Radiation Use Efficiency in Double-Cropped Wheat-Cotton. Field Crops Research, 170, 21-31. https://doi.org/10.1016/j.fcr.2014.09.013

[24] Sawan, Z.M., Hafez, S.A. and Basyony, A.E. (2001) Effect of Nitrogen Fertilization and Foliar Application of Plant Growth Retardants and Zinc on Cottonseed, Protein and Oil Yields and Oil Properties of Cotton. Journal of Agronony and Crop Science, 186,183-191. https://doi.org/10.1046/j.1439-037X.2001.00473.x

[25] Sawan, Z.M., Hafez, S.A., Basyony, A.E. and Alkassas, A.E.R. (2007) Cottonseed: Protein, Oil Yields, and Oil Properties as Influenced by Potassium Fertilization and Foliar Application of Zinc and Phosphorus. GrasasAceites, 58, 40-48.

https://doi.org/10.3989/gya.2007.v58.i1.7

[26] Raun, W.R. and Johnson, G.V. (1999) Improving Nitrogen Use Efficiency for Cereal Production. Agronomy Journal, 91, 357-363. https://doi.org/10.2134/agronj1999.00021962009100030001x

[27] Zhu, Z. and Chen, D. (2002) Nitrogen Fertilizer Use in China-Contributions to Food Production, Impacts on the Environment and Best Management Strategies. Nutrition and Cycling Agroecosyst, 63, 117-127. https://doi.org/10.5860/CHOICE.42-5837

[28] Foley, J.A., Ramankutty, N., Brauman, K.A., Cassidy, E.S., Gerber, J.S., Johnston, M., et al. (2011) Solutions for a Cultivated Planet. Nature, 478, 337-342. https://doi.org/10.1038/nature10452 
[29] Mueller, N.D., Gerber, J.S., Johnston, M., Ray, D.K., Ramankutty, N. and Foley, J.A. (2012) Closing Yield Gaps Through Nutrient and Water Management. Nature, 490, 254-257. https://doi.org/10.1038/nature11420

[30] Hefferon, K.L. (2015) Nutritionally Enhanced Food Crops; Progress and Perspectives. International Journal of Molecular Sciences, 16, 3895-3914. https://doi.org/10.3390/ijms16023895

[31] Turley, R.B. and Kloth, R.H. (2002) Identification of a Third Fuzzless Seed Locus in Upland Cotton (Gossypium hirsutum L.). Journal of Hereditary, 93, 359-364. https://doi.org/10.1093/jhered/93.5.359

[32] Turley, R.B., Vaughn, K.C. and Scheffler, J.A. (2007) Lint Development and Properties of Fifteen Fuzzless Seed Lines of Upland Cotton (Gossypium hirsutum L.). Euphytica, 156, 57-65. https://doi.org/10.1007/s10681-006-9351-9

[33] Bellaloui, N. and Turley, R.B. (2013) Effects of Fuzzless Cottonseed Phenotype on Cottonseed Nutrient Composition in Near Isogenic Cotton (Gossypium hirsutum L.) Mutant Lines under Well-Watered and Water Stress Conditions. Frontiers in Plant Science, 4, 516. https://doi.org/10.3389/fpls.2013.00516

[34] Bellaloui, N., Stetina, S.R. and Turley, R.B. (2015) Cottonseed Protein, Oil, and Mineral Status in Near-Isogenic Gossypium hirsutum Cotton Lines Expressing Fuzzy/Linted and Fuzzless/Linted Seed Phenotypes under Field Conditions. Frontiers in Plant Science, 6, 137. https://doi.org/10.3389/fpls.2015.00137

[35] Turley, R.B., Stetina, S.R., Bellaloui, N. and Molin, W. (2019) Comparison of Growth, Yield and Fiber Quality of the Obsolete SA30 Yellow Leaf with Four Sets of Modern Yellow and Green Leaf Near Isogenic Cotton (Gossypium hirsutum L.) Lines. Journal Cotton Science. (In Press)

[36] Zhu, J., Chen, J., Gao, F., Xu, C., Wu, H., Chen, K., et al. (2017) Rapid Mapping and Cloning of the Virescent-1 Gene in Cotton by Bulked Segregant Analysis-Next Generation Induced Gene Silencing Strategies. Journal of Experimental Botany, 68, 4125-4135. https://doi.org/10.1093/jxb/erx240

[37] Mao, G., Ma, Q., Wei, H., Su. J., Wang, H., Ma, Q., Fan, S., Song, M., Zhang, X. and Yu, S. (2018) Fine Mapping and Candidate Gene Analysis of the Virescent Gene $\mathrm{v}_{1}$ in Upland Cotton (Gossypium hirsutum). Molecular Genetics and Genomics, 293, 249-264. https://doi.org/10.1007/s00438-017-1383-4

[38] Bellaloui, N., Mengistu, A., Walker, R.R. and Young, L.D. (2014) Soybean Seed Composition Affected by Seeding Rates and Row Spacing in the Midsouth USA. Crop Science, 54, 1782-1795. https://doi.org/10.2135/cropsci2013.07.0463

[39] Dumas, J.B.A. (1883) Procedes de l'analyse Organic. Annal de Chimie et de Physique, 247, 198-213.

[40] Holmes, F.L. (1963) Elementary Analysis and the Origins of Physiological Chemistry. Isis, 54, 50-81. https://doi.org/10.1086/349664

[41] Childs, C.E. and Henner, E.B. (1970) A Direct Comparison of the Pregl, Dumas, Perkin-Elmer, and Hewlett-Packard (F\&M) Carbon-Hydrogen-Nitrogen Procedures. Microchemical Journal, 15, 590-597. https://doi.org/10.1016/0026-265X(70)90102-5

[42] Bellaloui, N., Smith, J.R., Gillen, A.M. and Ray, J.D. (2011b) Effects of Maturity, Genotypic Background, and Temperature on Seed Mineral Composition in Near Isogenic Soybean Lines in the Early Soybean Production System. Crop Science, 51, 1161-1171. https://doi.org/10.2135/cropsci2010.04.0187

[43] Lohse, G. (1982) Microanalytical Azomethine-H Method for Boron Determination in Plant Tissue. Communications in Soil Science and Plant Analysis, 13,127-134. https://doi.org/10.1080/00103628209367251 
[44] Dordas, C. (2006) Foliar Boron Application Affects Lint and Seed Yield and Improves Seed Quality of Cotton Grown on Calcareous Soils. Nutrient Cycling in Agroecosystems, 76, 19-28. https://doi.org/10.1007/s10705-006-9037-7

[45] John, M.K., Chuah, H.H. and Neufeld, J.H. (1975) Application of Improved Azomethine-H Method to the Determination of Boron in Soils and Plants. Analytical Letters, 8, 559-568. https://doi.org/10.1080/00032717508058240

[46] Bandemer, S.L. and Schaible, P.J. (1944) Determination of Iron. A Study of the Ophenanthroline Method. Industrial \& Engineering Chemistry Analytical Edition, 16, 317-319. https://doi.org/10.1021/i560129a013

[47] Loeppert, R.L. and Inskeep, W.P. (1996) Colorimetric Determination of Ferrous Iron and Ferric Iron by the 1,10-Phenanthroline Method. In: Bigham, J.M., Ed., Methods of Soil Analysis. Part 3, Chemical Methods, SSSA, Madison, 659-661.

[48] Cavell, A.J. (1955) The Colorimetric Determination of Phosphorus in Plant Materials. Journal of Science and Food Agriculture, 6, 479-480. https://doi.org/10.1002/jsfa.2740060814

[49] AOAC Association of Official Analytical Chemists (1990) Method 988.05. In: Helrich, K., Ed., Official Methods of Analysis, 15th Edition, Elsevier Science Publishing, Arlington, 70.

[50] AOAC Association of Official Analytical Chemists (1990) Method 920.39. In: Helrich, K., Ed., Official Methods of Analysis, 15th Edition, Elsevier Science Publishing, Arlington, 71.

[51] SAS Institute (2002-2012) SAS. SAS Institute, Cary.

[52] Sawan, Z.M., Hafez, S.A., Basyony, A.E. and Alkassas, A.E.E. (2006) Cottonseed, Protein, Oil Yields and Oil Properties as Influenced by Potassium Fertilization and Foliar Application of Zinc and Phosphorus. World Journal of Agriculture Science, 2, 66-74. https://doi.org/10.3989/gya.2007.v58.i1.7

[53] Mengel, K. and Kirkby, E.A. (1982) Principles of Plant Nutrition. 3rd Edition, International Potash Institute, Worblaufen-Bern.

[54] Sangakkara, U.R., Frehner, M. and Nösberger, J. (2000) Effect of Soil Moisture and Potassium Fertilizer on Shoot Water Potential, Photosynthesis Partitioning of Carbon in Mungbean and Cowpea. Journal of Agronomy and Crop Science, 185, 201-207. https://doi.org/10.1046/j.1439-037x.2000.00422.x

[55] Oosterhuis, D., Hake, K. and Burmester, C. (1991) Foliar Feeding Cotton. The Newsletter of the Cotton Physiology Education Program, the National Cotton Council. Physiology Today, 2, 1-7.

[56] Marschner, P. (2012) Marschner's Mineral Nutrition of Higher Plants. 3rd Edition, Academic Press, San Diego.

[57] Rodriguez, D., Zubillaga, M.M., Ploschuck, E., Keltjens, W., Goudriaan, J. and Lavado, R. (1998) Leaf Area Expansion and Assimilate Prediction in Sunflower Growing under Low Phosphorus Conditions. Plant and Soil, 202, 133-147. https://doi.org/10.1023/A:1004348702697

[58] Taiz, L. and Zeiger, E. (1991) Plant Physiology: Mineral Nutrition. The Benjamin Cummings Publishing, Redwood City.

[59] Aladakatti, Y.R. (2006) Effect of Foliar Application of Micronutrients on Seed Yield and Quality of Cotton Hybrid DHH-11. Thesis, the University of Agricultural Sciences, Dharwad.

[60] Rajeswari, R.V. (1996) Foliar Application of Growth Regulators and Nutrients on Boll Development and Yield in Cotton. Journal of the Indian Society for Cotton 
Improvement, 21, 71.

[61] Rathinavel, K., Dharmalingam, C. and Paneersewam, S. (1999) Effect of Micronutrient on the Productivity and Quality of Cotton Seed Cv. TCB 209 (Gossypium barbadense L.). Madras Agricultural Journal, 86, 313-316.

[62] Ahlawat, I.P.S. (1974) A Note on Response of Cotton (Gossypium hirsutum) to Soil and Foliar Application of Micronutrients. Indian Journal of Agronomy, 19, 71-74.

[63] Khuzhanazarov, S.H., Dzhumaev, N. and Mamanov, S.H. (1983) Effect of Copper and Zinc in the Composition of Basal Fertilizer on Yield of Fine Fibred Cotton. Field Crop Abstracts, 37, 780.

[64] Bolek, Y., Tekerek, H., Hayat, K. and Bardak, A. (2016) Screening of Cotton Genotypes for Protein Content, Oil and Fatty Acid Composition. Journal of Agriculture Science, 8, 107-121. https://doi.org/10.5539/jas.v8n5p107

[65] Hinze, L.L., Horn, P.J., Kothari, N., Dever, J.K., Frelichowski, J., Chapman, K.D. and Percy, R.G. (2015) Nondestructive Measurements of Cottonseed Nutritional Trait Diversity in the U.S. National Cotton Germplasm Collection. Crop Science, 55, 770-782. https://doi.org/10.2135/cropsci2014.04.0318

[66] Shaver, T.N. and Dilday, R.H. (1982) Measurement of and Correlations among Selected Seed Quality Factors for 36 Texas Race Stocks of Cotton. Crop Science, 22, 779-781. https://doi.org/10.2135/cropsci1982.0011183X002200040019x

[67] Cherry, J.P., Kohel, R.J., Jones, L.A. and Powell, W.H. (1986) Food and Feeding Quality of Cottonseed. In: Mauney, J.R. and Stewart, J.M., Eds., Cotton Physiology, The Cotton Foundation, Memphis, 557-596.

[68] Gotmare, V., Singh, P., Mayee, C.D., Deshpande, D. and Bhagat, C. (2004) Genetic Variability for Seed Oil Content and Seed Index in Some Wild Species and Perennial Races of Cotton. Plant Breeding, 123, 207-208. https://doi.org/10.1046/j.1439-0523.2003.00914.x

[69] Khan, N.U., Marwat, K.B., Hassan, G., Ullah, F., Batool, S., Makhdoom, K., Ahmad, W. and Khan, H.U. (2010) Genetic Variation and Heritability for Cotton Seed, Fiber and Oil Traits in Gossypium hirsutum L. Pakistan Journal of Botany, 42, 615-625.

[70] Carvalho, L.P.D., Rodrigues, J.I.D.S. and Farias, F.J.C. (2017) Selection of Cotton Lines for High Oil Content. Pesquisa Agropecuária Brasileira, Brasília, 52, 530-538. https://doi.org/10.1590/s0100-204x2017000700007

[71] United States Census Bureau. Population by Region and Country: 1950-2050, Census.

https://www.census.gov/search-results.html?stateGeo=none\&q=world+population+ 1950-2050\&searchtype $=$ web

[72] Strand, Å., Asami, T., Alonso, J., Ecker, J.R. and Chory, J. (2003) Chloroplast to Nucleus Communication Triggered by Accumulation of Mg-Protoporphyrin IX. Nature, 421, 79-83. https://doi.org/10.1038/nature01204

[73] Sugimoto, H., Kusumi, K., Tozawa, Y., Yazaki, J., Kishimoto, N., Kikuchi, S. and Iba, K. (2004) The Virescent-2 Mutation Inhibits Translation of Plastid Transcripts for the Plastid Genetic System at an Early Stage of Chloroplast Differentiation. Plant and Cell Physiology, 45, 985-996. https://doi.org/10.1093/pcp/pch111

[74] Kamal-Eldin, A. and Appelqvist, L.A. (1994) Variation in Fatty Acid Composition of the Different Acyl-Lipids in Seed Oils from Four Sesamum Species. Journal of American Oil Chemists' Society, 71, 135-139. https://doi.org/10.1007/BF02541547

[75] Piper, E.L. and Boote, K.J. (1999) Temperature and Cultivar Effects of Soybean Seed Oil and Protein Concentration. Journal of American Oil Chemists' Society, 76, 
1233-1241. https://doi.org/10.1007/s11746-999-0099-y

[76] May, W.E., Hume, D.L. and Hale, B.A. (1993) Effects of Agronomic Practices on Free Fatty Acid Levels in the Oil of Ontario-Grown Spring Canola. Canadian Journal of Plant Science, 74, 267-274. https://doi.org/10.4141/cjps94-053

[77] Dardanelli, J.L., Balzarini, M., Martinez, M.J., Cuniberti, M., Resnik, S., Ramunda, S.F., Herrero, R. and Baigorri, H. (2006) Soybean Maturity Groups, Environments, and Their Interaction Define Mega-Environments for Seed Composition in Argentina. Crop Science, 46, 1939-1947. https://doi.org/10.2135/cropsci2005.12-0480

[78] Bellaloui, N., Smith, J.R., Ray, J.D. and Gillen, A.M. (2009) Effect of Maturity on Seed Composition in the Early Soybean Production System as Measured on Near-Isogenic Soybean Lines. Crop Science, 49, 608-620.

https://doi.org/10.2135/cropsci2008.04.0192 